\title{
Molecular Methods as Potential Tools in Ecohydrological Studies on Emerging Contaminants in Freshwater Ecosystems
}

\author{
Elzbieta Mierzejewska ${ }^{1, *(D)}$ and Magdalena Urbaniak ${ }^{2}$ \\ 1 UNESCO Department of Ecohydrology and Applied Ecology, Faculty of Biology and Environmental \\ Protection, University of Lodz, 90-237 Lodz, Poland \\ 2 Department of Biochemistry and Microbiology, Faculty of Food and Biochemical Technology, \\ University of Chemistry and Technology Prague, 16628 Prague, Czech Republic; \\ magdalena.urbaniak@vscht.cz \\ * Correspondence: elzbieta.mierzejewska@unilodz.eu
}

Received: 18 September 2020; Accepted: 19 October 2020; Published: 22 October 2020

\begin{abstract}
Contaminants of emerging concern (CECs) present a threat to the functioning of freshwater ecosystems. Their spread in the environment can affect both plant and animal health. Ecohydrology serves as a solution for assessment approaches (i.e., threat identification, ecotoxicological assessment, and cause-effect relationship analysis) and solution approaches (i.e., the elaboration of nature-based solutions: NBSs), mitigating the toxic effect of CECs. However, the wide array of potential molecular analyses are not fully exploited in ecohydrological research. Although the number of publications considering the application of molecular tools in freshwater studies has been steadily growing, no paper has reviewed the most prominent studies on the potential use of molecular technologies in ecohydrology. Therefore, the present article examines the role of molecular methods and novel omics technologies as essential tools in the ecohydrological approach to CECs management in freshwater ecosystems. It considers DNA, RNA and protein-level analyses intended to provide an overall view on the response of organisms to stress factors. This is compliant with the principles of ecohydrology, which emphasize the importance of multiple indicator measurements and correlation analysis in order to determine the effects of contaminants, their interaction with other environmental factors and their removal using NBS in freshwater ecosystems.
\end{abstract}

Keywords: ecohydrology; CECs; freshwater; molecular analysis; DNA; RNA; proteins

\section{Introduction}

\subsection{Contaminants of Emerging Concern-Definitions}

Recently, contaminants of emerging concern (CECs), also known as emerging contaminants, have received a great deal of attention throughout the scientific world. The core definition of CECs is "any synthetic or naturally occurring chemical or any microorganism that is not commonly monitored in the environment, but has the potential to enter the environment and cause known or suspected adverse ecological and/or human health effects" [1,2]. However, this definition can be understood in three distinct ways:

1. CECs are new compounds whose presence in nature has not been recorded before;

2. CECs are contaminants that for a long time have not been considered as biohazards;

3. CECs are old contaminants that are now becoming problematic [3]. 
The term CEC was first coined more than 30 years ago; however, many emerging contaminants were first introduced to the environment during the rapid agricultural and pharmaceutical development observed after World War II [3]. To define the regulations for their use, there is a constant need for more data concerning CECs, such as endocrine-disrupting chemicals (EDCs) and a wide range of pharmaceuticals and personal care products (PPCPs) such as analgesics, antibiotics, hormones, anti-inflammatory, antidiabetic, antiviral, and psychoactive drugs [2]. These compounds nowadays represent a threat for freshwater ecosystems, especially because they remain intact following wastewater treatment or emerge as by-products. Extensive studies of the consequences of their spread in the environment and their effect on human health are needed to establish sustainable solutions for their management, removal and mitigation of their toxic effect [2].

\subsection{Ecohydrological Approach for the Management and Removal of CECs}

To ensure the good health of freshwater ecosystems and secure human health, it is necessary to reduce the level of pollution by CECs. An interesting solution for the management and removal of CECs from the environment is based on the integration of different research fields and the application of sustainable nature based solutions (NBSs). The ecohydrology approach can hence serve as a platform for science exchange and an integrative view on CECs control.

Ecohydrology is an interdisciplinary science that integrates knowledge on hydrology and ecology in order to enhance the resilience of catchment and develop sustainable ecological biotechnologies $[4,5]$. The most important aspect of ecohydrology is that it considers interrelations between catchment, habitats and biological processes such as succession and nutrient circulation. Descriptions of these dependencies are used in ecotoxicological risk management for water quality improvement [4], biomonitoring, preservation of biodiversity in freshwater ecosystems, resilience of ecosystems to contaminants, and management and sustainable development of environmental biotechnologies. The ecohydrology concept has been defined by three main principles that can be used to assess the risks and opportunities associated with critical catchment areas and describe the hierarchy of biotic and abiotic factors in catchments located in different climate zones, these being hydrological principle, ecological principle and ecological engineering principle [5]. They describe and explain the 'absorbing capacity' of an ecosystem against human impact and the adaptation mechanisms and resistance/resilience of ecosystems to stress factors. Still the majority of ecohydrological research is concerned about the effects of anthropogenic activities (i.e., agricultural and industrial) on the changes of water circulation caused by changing hydrological conditions due to the progressive climate changes. The dispersion of pollutants from point and non-point sources can substantially weaken the self-purification potential, cause physiological changes in living organisms and thus reduce migration of organisms along the river continuum. Hence, the spread and accumulation of CECs can soon become the dominating limitation of ecosystem services of flowing water systems. However, still the ecohydrological approach has not been fully exploited in terms of the effects and removal of CECs from aquatic ecosystems.

The ecohydrological approach serves as a base for problem identification (assessment approach) and problem solving (solution approach), and follows a four-step methodology (Figure 1) [5]. The assessment approach uses a broad spectrum of analyses to determine the concentration of the CECs and their toxicity with regard to the individual components of the ecosystem (i.e., threat monitoring). The results subsequently can clarify the interactions and processes that affect pollutant levels (i.e., analysis of cause-effect relationships). The solution approach is then used to improve the quality of the environment (i.e., elaboration of methods for reducing identified threats). Subsequently, systematic NBSs are developed and applied in critical areas to achieve a good ecological status and environmental improvement (Figure 1).

The most pronounced assumption of Ecohydrology is that biological elements and parameters of the ecosystems (e.g., biodiversity and bioproductivity) are determined by the hydrological cycle and vice versa: hydrological conditions are shaped by biotic processes. This is so called 
dual regulation, which is based on two-directional water-biota interplay [4]. Thus, water quantity and quality influence the dispersion of CECs and hence, their bioavailability for terrestrial and aquatic organisms. The retention and translocation of CECs in the environment strictly depends on their characteristics, which are described by various physicochemical parameters including solubility in water, $\log \mathrm{P}$ (octanol-water partition coefficient), $\mathrm{K}_{\mathrm{oc}}$ (organic carbon normalized adsorption coefficient) and Henry's law constant [6]. Contaminants can be partitioned between the aqueous phase, solid organic matter and minerals, and thus, they can be transported together with intensified surface run-off and reach surface water sources. The amount of CEC residuals transported to water reservoirs with surface run-off and their effect on biota depends on several factors, such as initial quantity of the contaminant, commercial formulations, climate conditions (e.g., precipitation, temperature), hydrological characteristics of water reservoir (e.g., volume, depth, streamflow), the presence of both artificial and natural barriers to the transfer of soil/sediment particles, plant cover, soil management and irrigation systems $[7,8]$. Some CECs, which are highly soluble in water, can leach into groundwater and contaminate important drinking water sources. Additionally, prevailing climate changes can also significantly influence the hydrological conditions, causing severe weather events, especially high rainfall and flooding; such events increase the mobilization of pollutants and their spread in freshwater ecosystems [8]. Subsequently, the residuals of CECs can be removed by spontaneous volatilization, adsorption, hydrolysis, biodegradation, photodegradation, uptake, and metabolism. However, these processes can be altered by various factors including the characteristics of the water reservoir, climate conditions and biodiversity [8]. A fraction of CECs can also be transported and retained by sediment particles for a long time or absorbed by living organisms and bioaccumulated in trophic chains. Hence, the assessment of biotope-biocenosis interactions in terms of CECs dispersion is a complex issue and one that is unfortunately often neglected.

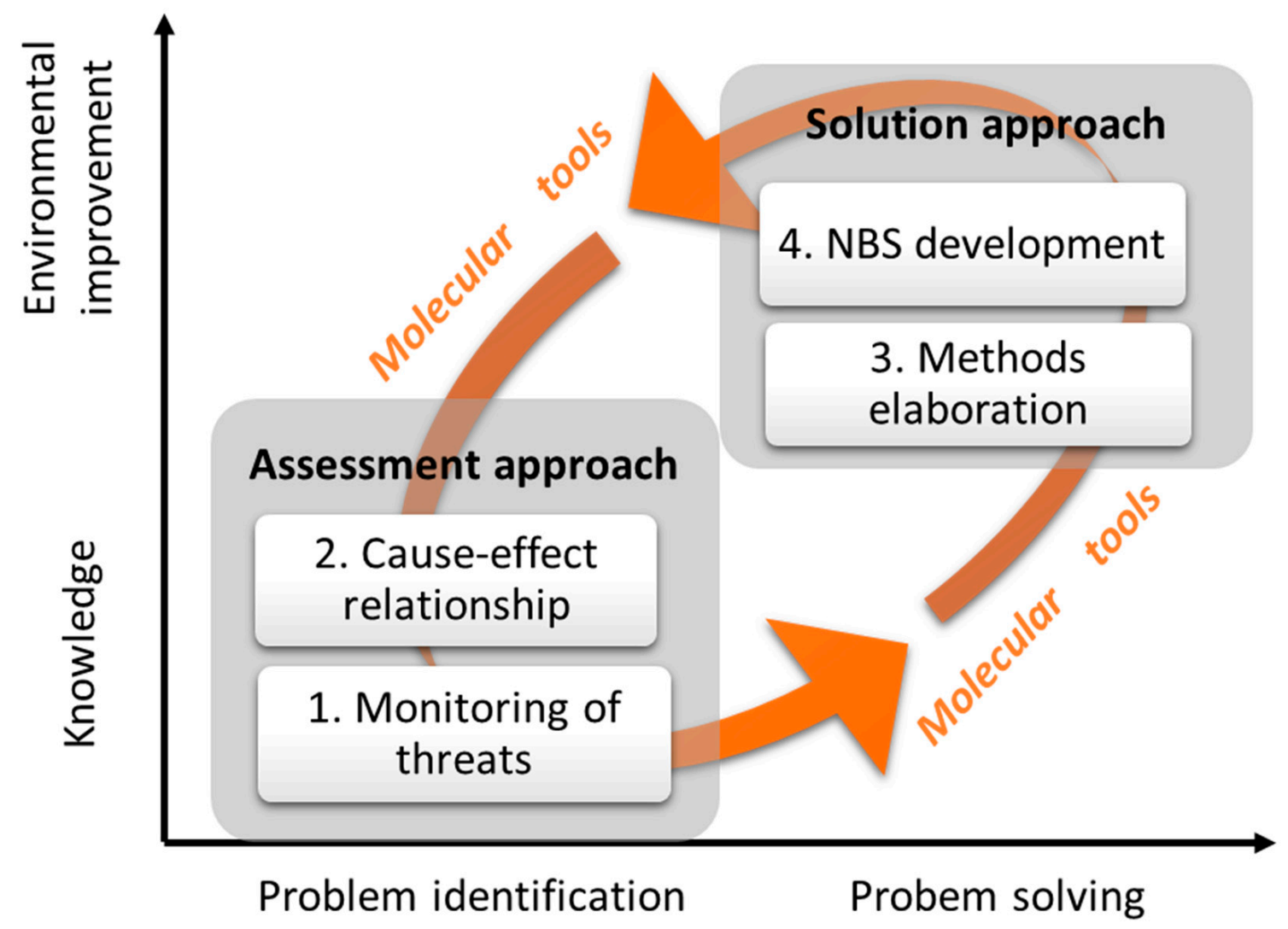

Figure 1. Molecular methods as integrating ecohydrology tools for problem identification and problem solving: from the assessment approach (gaining knowledge) to solution approach (environmental improvement). 


\subsection{Molecular Tools in Freshwater Ecosystem Research}

To gain a fuller understanding of the ongoing processes taking place in freshwater ecosystems, it is necessary to use an interdisciplinary approach that enables data to be obtained on all levels of biological organization. Molecular tools can be used to integrate assessment and solution approaches (Figure 1) on different levels of biological organization, thus providing a greater understanding of the underlying responses of living organisms to CECs and allowing the development of a methodology for enhancing environmental status. Hence, the last 30 years have seen the development of a range of novel-omics approaches and molecular tools for use in freshwater ecology [9].

The use of environmental genetics, genomics and transcriptomics provides a clearer view of the genetic variation between populations; it can also identify susceptible genes and the response of organisms to stress factors on the DNA level and indicate key regulatory genes and pathways using comparative genomics with model organisms [10]. Polymerase chain reaction (PCR) and its modifications (e.g., qualitative PCR, qPCR; reverse transcriptase-qPCR, RT-qPCR) have revolutionized traditional analytical methods in biology. All these approaches are based on the enzymatic amplification of DNA or complementary DNA (cDNA) using thermostable polymerase and two specific primers that target the DNA fragment of interest [11]. Several applications, such as DNA profiling (using microsatellites), comet assay (single cell gel electrophoresis) or Hoechst fluorimetry, can quantify DNA impairments by visualizing the distribution of different DNA strand lengths and their relative mobility in a gel. Additionally, reporter gene assays based on enzymes such as luciferase, $\beta$-galactosidase, or green fluorescent protein, have been found to be efficient tools for monitoring the toxicological effect of contaminants on cell activities [12] by detecting the agonist/antagonist of receptors and evaluating the disrupting activity of environmental contaminants [13].

A number of recent environmental studies have employed approaches based on genetic diversity assessment. For example, denaturing gradient gel electrophoresis (DGGE) has been used extensively in microbial ecology in order to separate ribosomal DNA (rDNA) fragments [14] according to sequential differences. Metagenomic and metatranscriptomic analysis using high throughput sequencing (HTS) can show the influence of environmental factors on the genome and transcriptome of a studied organism and the community composition and activity especially for bacteria and fungi [15]. Some other PCR-related methods such as terminal restriction fragment length polymorphism (T-RFLP) and amplified fragment length polymorphism (AFLP), based on the digestion of studied DNA with restriction enzymes [16], can be used in effect-based monitoring strategies recommended in European guidelines [17]. Another genetic diversity assessment approach is fluorescence in situ hybridization (FISH), which is a cytogenetic method for the detection, analysis and quantification of nucleic acids on the genome and transcriptome level [18]. In addition, a common technique applied to evaluate the microbial communities in freshwater environment is automated ribosomal intergenic spacer analysis, a PCR-based approach that analyses the 16S-23S intergenic spacer region using a fluorescence-labeled forward primer [19].

As genetic data can give only a limited view of the whole environmental picture, transcriptomic and proteomic analyses (activity-focused approaches) [15] have been gaining popularity in environmental studies [9]. However, proteomics has been used less extensively in recent years as sophisticated analyses such as the separation and identification of the target proteins and study of their functions using 2-dimensional electrophoresis (2-DE) or shotgun proteomics, are expensive to perform [20].

In Web of Science [21], the number of documents considering freshwater systems and the use of molecular tools (Figure 2) grew until 2019; this body comprised 41,287 ( 94\%) research articles and 1897 $(\sim 4 \%)$ review papers, with the main categories being Marine Freshwater Biology, Ecology, Microbiology, and Genetics Heredity (Figure 3A). Although the number of CEC studies based on molecular tools is steadily increasing, there remains a growing need to enlarge the database on this subject. In the period 1991-2019, 780 research articles and 52 reviews considering freshwater ecosystems, molecular tools and CECs were published, indicating that only a small fraction of the total number of publications on the application of molecular tools in freshwater study concern CECs; although admittedly, these results are 
dependent on the choice of search term. Interestingly, research on CECs has been assigned to a number of Web of Science categories, but mainly Environmental Sciences, Toxicology, Marine Freshwater Biology, and Endocrine Metabolism (Figure 3B). It is also visible that more attention has been paid to persistent organic pollutants and heavy metals such as $\mathrm{Pb}, \mathrm{Cd}, \mathrm{Ni}$ etc. and a great number of research articles are based on model studies performed under in vitro conditions.

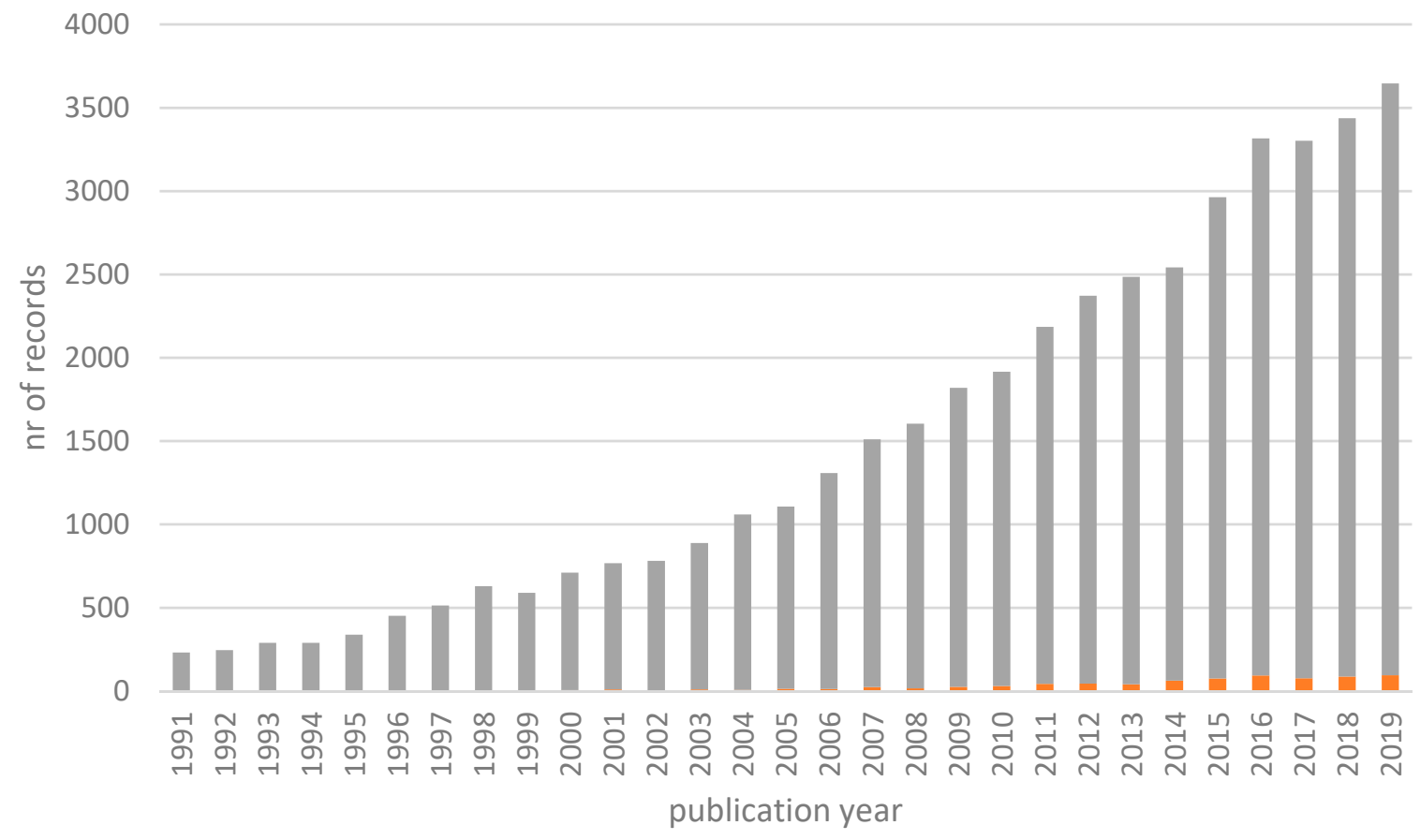

nr of records about CEC $\quad$ nr of all records

Figure 2. Results from a Web of Science Search 1991-2019 (2020 excluded) [21] search. Grey color: using the key words TOPIC: ("molecular biology" OR genetic* OR genom* OR DNA OR eDNA OR transcript* OR RNA or mRNA or proteome*) AND TOPIC: (freshwater OR "fresh water" OR fresh-water OR river OR lake OR wetland* OR "dam reservoir"); orange color: using the key words TOPIC: ("molecular biology" OR genetic* OR genom* OR DNA OR eDNA OR transcript* OR RNA or mRNA or protein or proteom*) AND TOPIC: (freshwater OR "fresh water" OR fresh-water OR river OR lake OR wetland* OR "dam reservoir") AND TOPIC: ("emerging contaminant" OR "emerging pollutant" OR "CEC" OR "contaminants of emerging concern" OR pharmaceutical* OR radionuclide* OR “endocrine disrupt*” OR tungsten OR "polybrominated diphenyl ether*" OR PBDE OR trichloropropane OR TCP OR dioxane OR trinitrotoluene OR TNT or dinitrotoluene or "hexahydrotrinitrotriazane" or RDX or perchlorate OR "polybrominated biphenyl" or PFOS or "perfluorooctane sulfonate acid" or PFOA or plasticizer* or "personal care product*" OR PCPC or perfluoroalkyl or "chlorinated paraffin" ${ }^{*}$ or siloxane* OR microplastic*); $\mathrm{nr}=$ number.

Recent review papers have focused mainly on freshwater sources contaminated with certain CECs, particularly EDCs [22-26], and various pharmaceuticals such as antibiotics [27-29], antidepressants [30], antiretrovirals [31], and residues of paracetamol and ibuprofen [32]. Other studies have focused on the development of new high-throughput bioassays for toxicological assessment using aquatic animal embryo bioassays [33], novel determination of EDC concentrations in environmental samples [24], and bioassay of thyroid function disruption in fish [34]. Research on the restoration and remediation of freshwater ecosystems contaminated with CECs has placed particular emphasis on the bacterial decomposition of a group of compounds or single substances [29,35]. Few studies have examined the genomic, transcriptomic and proteomic aspects of ecohydrology [36]. Reviews considering omics analyses have focused mainly on either a single group of organisms [37] or single CECs [32]. 
A

- Marine Freshwater Biology

Ecology

- Microbiology

- Genetics Heredity

E other

- Environmental Sciences

- Toxicology

- Marine Freshwater Biology

- Endocrinology Metabolsim

घ other

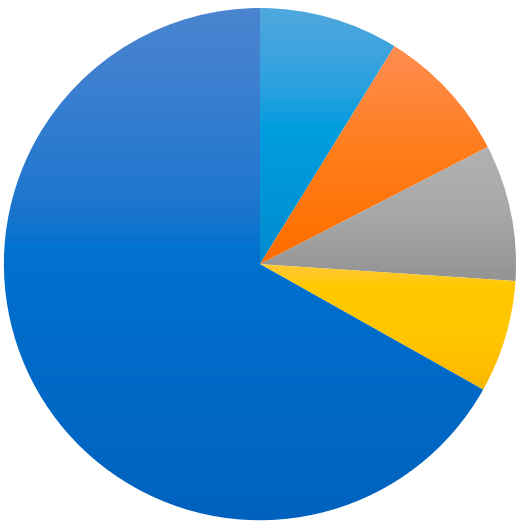

B

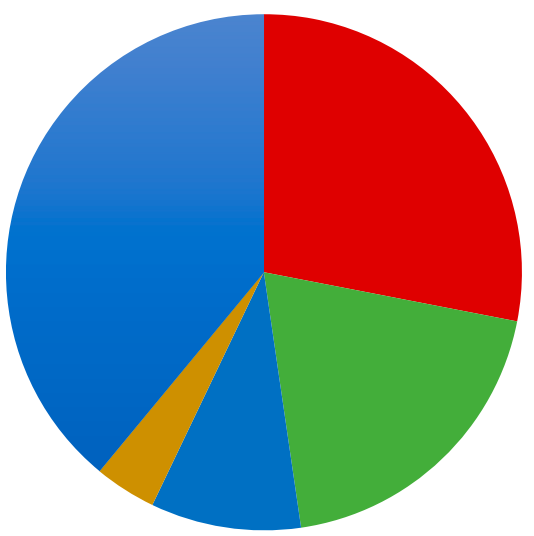

Figure 3. Results from a Web of Science 1991-2019 [21] according to Web of Science Categories: (A) using the key words TOPIC: (molecul* OR genetic* OR genom* OR proteom* OR transcript*) AND TOPIC: (freshwater OR "fresh water" OR fresh-water); (B) using key words: A- using the key words TOPIC: (molecul ${ }^{*}$ OR genetic* OR genom* OR proteom* OR transcript ${ }^{*}$ ) AND TOPIC: (freshwater OR "fresh water" OR fresh-water) AND TOPIC: ("emerging contaminant*" OR "emerging pollutant*" OR "CEC" OR "contaminants of emerging concern" OR pharmaceutical* OR radionuclide* OR "endocrine disrupt ${ }^{*}$ " OR tungsten OR "polybrominated diphenyl ether" ${ }^{*}$ OR PBDE OR trichloropropane OR TCP OR dioxane OR trinitrotoluene OR TNT or dinitrotoluene or "hexahydrotrinitrotriazane" or RDX or perchlorate OR "polybrominated biphenyl*" or PFOS or "perfluorooctane sulfonate acid" or PFOA or plasticizer* or "personal care product" OR PCPC or perfluoroalkyl or "chlorinated paraffin $^{* \prime \prime}$ or siloxane* OR microplastic*.

\subsection{Aim of the Study}

Hence, the aim of this review is to bring together examples of the use of molecular methods and novel omics technologies in freshwater-oriented research, and discuss the future trends, possibilities and limitations associated with their use in ecohydrological studies. The review is divided into sections with regard to the applicability and usefulness of molecular tools in the assessment of CECs on the freshwater ecosystem at three levels of cellular organization, viz. genomic (DNA), transcriptomic (RNA) and proteomic (protein). 


\section{Genomic Methods in CEC Studies}

\subsection{Genomics in Monitoring of CECs Threats to Freshwater Ecosystems and Analysis of Cause-Effect Relationships-Assessment Approach}

CECs can influence the functioning of ecosystems on the molecular level, and this will eventually lead to major changes on higher levels of biological organization. Hence, molecular markers can be employed in an assessment approach (Figure 1) for the purpose of early monitoring and diagnostics of threats caused by dispersion of CECs [36]. The changes in DNA composition occurring in response to CEC exposure are some of the most important indicators used in ecotoxicological studies and biological early warning systems, hence they can be used as bioindicators for assessing the influence of CECs on biotic systems before significant changes are visible [36].

DNA profiling One of the simplest techniques for assessing DNA damage is so-called DNA profiling, which is based on the migration distance of isolated DNA from studied tissues. This approach was used i.a. to assess the degree of DNA damage in studies on the effect of EDC contamination on spermatogenesis of Pelophylax bergeri (Italian pool frog) in the River Sarno [38]. Although it was a fast, cheap and easy method of analysis, it offered insufficient resolution to evaluate small nucleotide changes in DNA strands. Therefore, other molecular and biochemical parameters have been evaluated.

Comet assay Comet assay (single-cell gel electrophoresis) [39] has become a robust technique for the evaluation of DNA impairments (e.g., strand breaks, cross-linking) and thus the impact of environmental stress, i.e., contamination with CECs, on freshwater fauna. Yan et al. [40] used an active biomonitoring approach (ABM) to study the integrated biomarker response (IBM) for EDCs in Lake Taihu in China and their impact on fish Carassius auratus (goldfish). IBM integrates the biological and chemical parameters in the form of a multivariate data set and provides a reliable indication of the impact of contaminants on the environment, which is compliant with ecohydrology principles. In the study of Yan et al. [40] the impact of EDCs present in the lake water on the feminization of goldfish was assessed using comet assay and gonadal DNA. As DNA damage was found to increase with incubation time, and significant differences were observed with controls, it could be seen that natural fish populations were threatened with hormonal-related diseases and feminization of male individuals.

The comet assay was also used in biomonitoring studies targeted against pharmaceuticals, such as $17 \alpha$-ethinylestradiol (EE2), sulfamethoxazole (antibiotic), atenolol, and ibuprofen, as well as a plasticizer bisphenol A (BPA) and stimulant (caffeine) in Lake Dalong, China [41]. The bioeffects were estimated for fish Carassius carassius (crucian carp). The study examined the activity of three parameters, viz. ethoxyresorufin-O-deethylase, glutathione S-transferase, and catalase. Genomic damage was observed compared to controls after 7 days of exposure, which authors related to metabolite formation or reactive oxygen species generation after exposure to stress. The IBM evaluation found that the studied organisms faced an acute hazard, but not a long-term one.

In order to assay the genotoxicity and cytotoxicity of influents and effluents from hospitals, chemical processing plants and municipal waste water treatment plants (WWTPs), in vitro bioassays such as SOS/umuC [42] and comet assay with human hepatoma cells (HepG2) can be used [43]. However, the two approaches yielded different results, indicating that different contaminants are responsible for effects observed on different levels of biological organization. Hence, any assessment of ecotoxicity in freshwater sources should be conducted using molecular tools that show DNA damage in response to stress exposure, as these serve as early monitoring tools for risk management.

DNA quantification Rodriguez-Gil et al. [44] examined a range of cost-effective tools for monitoring irrigated areas in Mediterranean regions. The results provide a comprehensive illustration of the distribution of contamination and its effect on different trophic levels through the integration of various methods: the chemical analysis of water, sediment and biological samples; the assessment of plant development biomarkers including mitochondrial activity, lipid peroxidation, chlorophyll content, and total DNA amount in Polystichum setiferum (soft shield fern) (spores and gametophytes); and the assessment of acute animal toxicity using embryos of Danio rerio (zebrafish). DNA quantification, 
performed using Hoechst fluorimetry assay, indicated that water from irrigation channels displayed strong genotoxic effects, and hence, that water from irrigation channels should not be used for agricultural purposes. However, it is important to note that these studies were performed under laboratory conditions.

PCR (polymerase chain reaction) The spread of some CECs throughout the watercourse can be monitored by PCR. In this sense, molecular analysis are used not only for the early evaluation of toxic effects of CECs on the biotic part of ecosystems but also for the detection of genes that are nowadays classified as CECs i.e., antibiotic resistance genes (ARGs). As water is the main medium by which ARGs can spread through the environment, increasing numbers of studies are being devoted to determining the presence and spread of ARGs in the aquatic environment. One study has used standard PCR to determine the seasonal variations of selected $A R G$ s i.e., $\operatorname{tet} A$, tet $B$, tet $C$, tet $D$, and tetE (tetracycline); $b l a_{O X A}, b l a_{S H V}, b l a_{T E M}$, and bla ${ }_{C T X-M}(\beta$-lactam); $m l s$ (macrolide, lincosamide and streptogramin); $\operatorname{ermF}$ and $\operatorname{lin} A$ (different antibiotics); sul1 (sulfonamides); aac ( $6^{\prime}$ )-Ib-cr (fluoroquinolones); int1 (integrase 1); and the $16 \mathrm{~S}$ rRNA in Pilica river [45]. The presence of $b l a_{T E M}, t e t A$, tet $E$, ermF, and $\operatorname{lin} A$ was confirmed in nearly all studied water samples, regardless of sampling date and site; however, no pattern was observed along the river continuum. The ARGs were the most abundant in samples collected during winter season, probably due to the fact that within this period bacterial infections are more common. Additionally, screening for ARGs indicated that the pollution of Pilica river has its source in point sources and runoff from agricultural fields and recreational areas. The authors indicated also that in order to determine the effect of microbiological contamination on other components of river ecosystem, there is a need for further ecohydrological research within the watercourse. Another study confirmed the presence of nearly all the studied ARGs in water samples from the Pilica river [46]. Interestingly, a higher prevalence of ARGs was noted in spring than in summer, and in treated wastewater effluent from small WWTPs, indicating that those WWTPs are not effective in ARG removal. The limited efficiency of the traditional water treatment can be caused by prevailing hydrological conditions i.e., the torrential rain events that cause an intensive inflow of precipitation water.

qPCR allows the determination of ARG concentration (copy number). For example, it has been used for monitoring seasonal changes in ARG levels [47] to assess the risk of dispersion of livestock antibiotics in freshwater sources used for domestic purposes and in industrial WWTPs. In total, 11 ARGs were tested: tet $A$, tetX; sul1; ermB, ermC; qnrS, aac (6')-lb-cr; floR (florfenicol); bla $a_{T E M}, b l a_{S H V}$; and oqxA (multidrug). The results indicated an alarming abundance of ARGs in drinking water, showing that the water treatment was insufficient for removing antibiotic residuals. The levels of the ARGs were found to increase in the warmest and coldest months, i.e., August and January. Additionally, the highest abundance was observed for three studied genes, viz. tet $A$, sul1 and $b l a_{T E M}$. In another study, qPCR was used to monitor the spread of a set of ARGs in a river system supplying a drinking water reservoir that was regularly subjected to discharge from two WWTPs [48]. The results found the ARG copy numbers to be significantly higher downstream of the WWTPs, indicating the WWTPs to be point sources of ARG pollution. Additionally the concentration of antibiotic residues, measured using liquid chromatography-mass spectrometry (LC-MS), followed the same pattern.

Reporter gene assay Another useful method is reporter gene assay, which allows the toxic effect of contaminants to be assessed on cell activities [12]. A study by Hu et al. [13] used luciferase gene activity as a reporter to measure the disrupting activity of thyroid hormone in CV-1 cells. The cells were exposed to water from several sites in the Yangtze River, China, contaminated with the plasticizers di-n-butyl phthalate (DNBP), di-2-ethylhexylphthalate (DEHP), nonylphenol (NP) and octylphenol (OP). It was found that the expression of luciferase was dependent on the concentration of contaminants and that DNBP had a strong antagonistic effect on thyroid receptors.

Luciferase was also used as a reporter gene to study the thyroid- and estrogenic disruption potential of the EDCs present in WWTPs, Seine river water and a drinking water treatment plant in Paris, France, [49] using two bioluminescent cellular models. It was found that both thyroid-DCs and EDCs were observed in the influents of the studied WWTPs; however, EDCs demonstrated greater 
impact than the thyroid-disrupting compounds. As the WWTPs effectively removed the studied EDCs, their effluents demonstrated little risk for the environment. Although EDC contamination was confirmed in the river, no significant effect on cell function was detected. For the drinking water, almost all remaining EDCs were removed. The authors indicate that liquid samples were used in the study; however, it is important to note that studies on sewage sludge and sediments could yield different conclusions due to their effect on EDC accumulation.

Assessment of genetic diversity To assess the impact of CECs on freshwater living organisms and to evaluate changes in genetic diversity e.g., along river continuum or in the areas affected by point sources of pollution, a useful technique is microsatellite number estimation. A study by Miller et al. [50] assessed the influence of EDCs on the genetic diversity of Sander vitreus (walleye) in different river segments of the Mississippi River, USA, by analyzing changes in microsatellite DNA loci (Svi4, Svi18, Svi33, SviL, SviL6, Svi2, Svi6, Svi16, Svi20, and Svi26). Although other bioassays had identified physiological responses to contamination, no difference in genetic diversity was found, measured as allele frequencies and estrogenicity. The results indicate that genetic diversity increased from upstream to downstream due to the presence of a geographical barrier (i.e., increasing-by-distance) and dam reservoirs, but was not caused by the presence of presence of EDCs. Other complementary measures on higher level of molecular levels of organization indicated the effect of contaminants on physiological level in walleyes.

An additional technique for the characterization of communities, particularly microbial ones, is DGGE, which was used for the analysis of natural river water biofilm communities [51] as part of a microcosm study and to determine their exposure to three CECs, viz. caffeine, acetaminophenon and diclofenac. The analysis found the archaeal community to be sensitive to the studied contaminants; therefore, these organisms could be incorporated in batteries of bioassays and monitoring systems.

The use of microsatellites and DGGE analysis as biomarkers for population and conservation genetics has decreased following the development of HTS: a robust technique used for the characteristics of genetic diversity among different populations. HTS can be used to evaluate i.a. microorganism communities in freshwater sources. This approach can be a valuable stage in determining the self-purification services of ecosystems and their ability to adapt to CECs by enhancing the understanding of microbial dynamics. Illumina HTS revealed significant fluctuations among autochthonous freshwater pond microbial communities exposed to different concentrations of perfluorooctanoic acid (PFOA) [52]. Kim et al. 2018 [53] studied the effect of benzalkonium chloride, a widely-used disinfectant, on the antibiotic resistance of bacteria as part of a 3-year in vitro bioreactor study. HTS analysis of mixed microbial communities and isolates confirmed a strong shift of river sediment autochthonous bacterial communities over this period. Additionally, genomic sequence analysis confirmed that benzalkonium chloride exposure enhanced the growth of antibiotic resistance.

Another PCR-related method, which can be combined with HTS in an effect-based monitoring strategy recommended in European guidelines, is AFLP [17]. This technique was used to determine the impact of fluoropolymer plant on microbenthic invertebrates of the Bormida River (Piedmont region, Italy) to assess the genetic diversity of Hydropsyche modesta (caddisfly) living upstream and downstream of a pollution source [17]. This analysis revealed a significant divergence between populations that were exposed to PFOA and those that were not; however, further study is needed to confirm and clarify the effect of contaminant.

A useful molecular tool that can be used to identify single nucleotide polymorphisms (SNPs) is genotyping-by-sequencing technique. It was used to assess the genetic diversity of the freshwater crustacean Asellus aquaticus (water louse) along the gradient of Chernobyl radionuclide contamination in six lakes in Belarus and Ukraine [54]. The results showed a strong correlation between geographical distance and genetic diversity, with the radiation not demonstrating any significant influence on genetic differentiation. In this case, the authors hypothesized that these results might be caused by the lack of dose response, meaning the radiation dose had no effect on DNA sequence alterations, or possibly that the population had already recovered the exposure to radionuclides after the Chernobyl accident. 
They also propose that a larger sampling size would be beneficial for "small" effect evaluation. However, neither of the described studies showed any significant change in overall genetic diversity along the contamination gradient; more detailed studies on the transcriptome and proteome would provide better biomarkers for evaluating the influence of CECs on the physiology of the studied organisms.

ARISA is a common technique used to evaluate the microbial communities in freshwater environment [19]. In one in vitro study, ARISA based on qPCR associated with ARGs and microbial abundance was used to assess the role of microplastics in the spread of the int1 gene in a simulated system of a river environment with WWTP effluent entering the system [55]. The results showed both studied parameters demonstrated similar patterns: A higher numbers of microplastic particles were associated with a greater chance of forming biofilms of allochthonous microbiota from the WWTPs on plastisphere; this allowed the microorganisms to better survive and potentially spread ARGs in the environment.

\subsection{Genomics in Improvement and Evaluation of Ecological Biotechnologies Efficiency-Solution Approach}

Maintaining the ecological integrity and natural character of disturbed ecosystems is one of the main functions of methods elaboration and NBS development, which are important steps in the solution approach (Figure 1). The effective removal of contaminants from watercourse can be achieved using novel, environmentally-friendly technologies, which are designed for the reclamation of contaminated ecosystems and restoration to its natural state. Therefore a plethora of different molecular methods has been used in order to characterize, evaluate and enhance the processes of CECs removal from freshwater.

DNA quantification DNA quantification using Hoechst fluorimetry assay was used in Polystichum setiferum spores for an ecotoxicological assessment of heterogeneous photo-Fenton treatment intended to reduce pharmaceutical levels in selected rivers around Madrid, Spain [56]. The bioassays demonstrated that the toxic effect of CECs was effectively mitigated by passage though WWTPs; however, the chronic ecotoxic effect was not fully removed on the DNA level.

PCR Molecular techniques, such as PCR, can be used to evaluate the efficiency of constructed wetlands (CWs) for removal of particular CECs like ARGs. For example, Nowrotek et al. [57] estimated the efficiency of downflow CW, planted with Phalaris arundinacea (read canary grass), for the removal of three ARGs encoding resistance to disinfectants: sul1-3, int2, qacE $\Delta 1$. The presence of the selected genes was analyzed in: (1) rhizosphere soil of plant seedlings before transfer to the columns; (2) activated sludge that served as an inoculum; (3) tap water that was used to prepare artificially contaminated wastewater; (4) effluents; and (5) upper layer of substrate at different stages of the experiment. Although the presence of sulfonamide resistance genes changed over the course of the experiment, the studied ARGs were detected in relatively high numbers in both wastewater samples containing pharmaceutical compounds and in those without. The authors suggest that the presence of ARGs in non-amended wastewater can be explained by the presence of other environmental stressors e.g., heavy metals, which enhance the stability of ARGs. Additionally, the presence of ARGs in rhizospheric soil was explained by the enhanced resistance to several environmental stressors of rhizospheric bacteria. It was proposed that the performance of downflow $\mathrm{CW}$ for the removal of ARGs needs further investigation in order to quantify the number of gene copies, because qualitative PCR analysis showed only that the studied ARGs were neither removed nor emerged along the flow path.

Another assessment was performed on the role of ecological purification systems installed at the Jinze Reservoir, in the south-west region of Shanghai, based on a simultaneous estimation of gene copy number for 283 ARGs using a Wafergen SmartChip high-throughput qPCR system. Artificial floating islands and ecological slope protection with aquatic plants were installed in the south-west region of Shanghai to protect drinking water sources against antibiotic residues and mitigate their influence on the spread of ARGs [58]. In the course of the purifying process, both the antibiotic residues and ARG copy numbers declined, indicating the successful removal of emerging pollutants using NBS. 
Assessment of genetic diversity The abundance of microorganisms and their characteristics (i.e., microbial communities profiling) are important parameters for evaluating the removal efficiency of CECs from water. They characterize the biodiversity of organisms that are able to degrade the contaminants from water and support ecosystem functions. Below we describe several examples of research that were focused on the characterization of microbial communities using robust techniques.

A combination of DGGE fingerprinting with $16 \mathrm{~S}$ rRNA marker gene analysis was used to study river bacterio-plankton collected from Gunnislake, UK, to determine the efficiency of removal of cationic pharmaceuticals (chloroquinine, quinine, fluphenazine, levamisole) [59]. It was found that levamisole, the most neutral compound, exhibited the greatest removal during 21 days of incubation (19-13\%), whereas the concentrations of other compounds remained unchanged. The DGGE profiles visualized using Sybr Green I showed no significant differences between the communities of bacterio-plankton treated with levamisole and the control untreated samples. Long-term monitoring (22 weeks) of wetland mesocosms planted with Phragmites australis (perennial grass) contaminated with antibiotic ciprofloxacin by DGGE of $16 \mathrm{~S}$ rRNA fragments [60] found that although ciprofloxacin negatively influenced the community diversity at the beginning of experiment, the bacterial communities were found to recover after $2-5$ weeks.

Krauter et al. [61] evaluated the efficiency of wetland bioreactor for the long-term removal of nitrates and perchlorate (CEC) from contaminated groundwater. The wetlands vegetation was dominated with Typha (cattail) and Cyperus (sedge) species and no inoculum augmentation was observed in the system. The authors combined DGGE and sequencing of excised 16S rRNA fragments in order to assess the abundance of perchlorate degraders. After 3-week exposure, molecular analysis confirmed the presence of autochthonous facultative anaerobic bacteria in sediment capable of reducing perchlorate in situ.

Genomic methods i.e., sequencing can also be used to monitor and enhance the biodegradation processes of particular CECs by water microbiota. For example, it has been hypothesized that anaerobic degradation of pentabromodiphenyl ether (BDE-99) by an archaeal community in a water column can be enhanced by biochar. Biochar amendment had a significant influence on the biodiversity of archaeal communities in an artificial filtration system used for the removal of BDE-99 from polluted groundwater, as indicated by the 454 pyrosequencing of $16 \mathrm{~S}$ rDNA genes [62]. Such enhancement was attributed to the high sorption capacity of biochar for binding strongly hydrophobic compounds; this can mitigate the toxic effect of BDE-99 on the archaeal communities, which can take part in the removal of mentioned CECs.

$16 \mathrm{~S}$ rDNA sequencing has also been extensively used for biodegradation studies to provide a basis for in situ remediation of halogenated organic compounds contaminating environmental matrices. A study of the degradation of tetrachlorobisphenol A (TCBPA) by autochthonous microorganisms in Longtang River (Nepal) sediment, and the influence of abiotic conditions on their activity, found that after 160 days of sediment microcosm incubation, the samples treated with TCBPA demonstrated increased microbial diversity [63].

HTS was also used to determine the efficiency of removal of antibiotics by an integrated CW system at a Domestic Sewage Treatment Plant in Lin'an City of Zhejiang province, China [64]. Integrated CW efficiency was evaluated in relation to bacterial community structure by pyrosequencing of $16 \mathrm{~S}$ rDNA characteristics and relations. The results revealed an abundance of four bacterial clusters, which were crucial for the removal of three key groups of antibiotics: quinolones, sulfonamides and macrolides. The bacterial community profile was determined by the physicochemical parameters of water and the type of studied antibiotic.

HTS analysis of $16 \mathrm{~S}$ rDNA fragments was also used in combination with T-RFLP and qPCR to assess the diversity and dynamics of bacterial communities in saline and freshwater sediments during anaerobic debromination of polybrominated diphenyl ether [65]. The findings indicate that both the microbial community structure and dynamics are determined by the debrominating properties of the studied sediment. Although the marine sediments exhibited much higher debromination 
than freshwater at the beginning of the experiment, a significant increase of freshwater sediment debromination potential was observed after 30 days of incubation.

HTS has also been used for the sequencing of functional genes, such as the mlr $A B C D$ gene cluster, responsible for the degradation of cyanobacterial toxins (microcystins). The method was used as part of a phylogenetic and taxonomical analysis of strains isolated from Jeziorsko Reservoir, Poland [66]. This combination of microbiological and molecular approaches resulted in the identification of a novel strain, JEZ-8L, which effectively removes microcystins from water. Such analysis is a promising tool for novel NBS for the removal of the harmful effects of cyanobacterial blooms.

The abundances of archaeal and bacterial communities can also be compared using FISH [18]. In this case, hybridization was performed with the EUB338 Alexa488-labelled bacterial universal gene probe and the ARC915 Cy3-labelled archaea universal gene probe. FISH analyses showed that the archaea communities were more abundant than the bacterial ones, and hence, played a more significant role in the biodegradation of BDE-99.

\section{Transcriptomic Methods in CEC Studies}

\subsection{Transcriptomics in Monitoring of CEC Threats to Freshwater Ecosystems and Analysis of Cause-Effect Relationships-Assessment Approach}

In order to obtain more detailed understanding of the influence of CECs on biological elements of ecosystems, recently gene expression profiling has been widely exploited in ecological studies. In comparison to the genomic analysis, it gives more "real" and reliable information on the response of organisms to stressors. This technique can be used in assessment approach (Figure 1) for stressor identification, defining the threshold values for toxicants, and separating natural and anthropogenic processes. Accurate monitoring of gene expression in contaminated and uncontaminated (control) environments can be used to assemble a library of expression patterns in studied organisms exposed to toxicants, and subsequently identify very accurate biomarkers for early monitoring and warning system [67], because many CECs can induce the expression of selected genes not expressed constitutively, or the expression of genes expressed in lower amounts increases.

The influence of CECs on freshwater organisms can be evaluated using gene expression analysis. Among the range of studied and monitored genes encoding protein vitellogenin, vtg expression has been extensively used in studying the response of fish to EDCs. While sexually mature females are characterized by high $v$ tg expression, this should be silenced in males. A series of three experiments, including model and field studies, by Xuereb et al. [68] examined the expression profiles of $v t g$ in male Gammarus fossarum, an amphipod crustacean, in water artificially contaminated with two EDCs (nonylphenol and anti-androgen cyproterone) and WWTP effluent discharge. The main aim of the study was to confirm whether the expression of $v t g$ in male crustaceans is a reliable biomarker for studying its response to EDCs using calibrated real-time reverse transcription PCR (real-time RT-PCR). In both cases, i.e., in vitro and in situ exposure, vtg expression was induced in males; however, for the WWTP effluent variant it was not clear whether vtg expression was enhanced by the pollution or natural factors.

The mRNA profiles of the $v t g$ gene have also been used to assess the effect of selected steroidal and phenolic EDCs on the fish Hemiculter leucisculus [69] and to evaluate the use of ABM for early detection of trace contaminants [70]. Semi-quantitative RT-PCR has also been used in studies of ABM and IBM [71]. An in situ ecotoxicological assessment of the influence of mixed pollutants on the fish Mugilogobius abei in Guangzhou River, China, by He et al. [71] assessed the expression profile of several biomarkers i.e., cyp1A and $p$ - $g p$ in addition to chemical analysis. Cyp P450, Cyp1A P-and glycoprotein (P-gp) enzymes are responsible for the resistance, detoxification and biotransformation of CECs. It was found that the two studied profiles demonstrated differential responses: cyp $1 A$ showed higher long-term expression level in sites where the three studied quinolone concentrations were higher, whereas $p$ - $g p$ reached a high peak and then reduced significantly. Additionally $p$ - $g p$ expression gradually increased in sites where polycyclic aromatic hydrocarbon $(\mathrm{PAH})$ concentrations were higher. 
This study also demonstrated that molecular markers are often more sensitive than enzyme activity assays in integrated biomonitoring studies, but also that it is essential to study the expression profiles of different genes, because they can exhibit different sensitivities [71].

Other studies have found that the expression of the following genes can be used as biomarkers: cyp3A [70]; ar (androgen receptor) [72]; esr1 and esrb (estrogen receptor) [72]; dmrt1, foxI2 and sox9 (transcripts related to sex differentiation) [72]; gst $\alpha$ and ugt (involved in xenobiotic biotransformation) [73]; gpx, sod, cat, hsp70, $h s p 40$, and $h s p 27$ (antioxidant defense) [73-75]; $m t-I$ and $m t-I I$ (trace metal exposure) [73]; xpa and xpc (DNA repair) [73]; bax and casp3; (apoptosis) [73]; igf2 (growth) [73]; dio1, dio2, $\operatorname{tr} \alpha, \operatorname{tr} \beta$, and nis (thyroid hormone signaling pathway) [73]; mcyA and g91 (cyanotoxins production) [76]; and cyp4 (cytochrome P450), sod (superoxide dismutase), and $m d r 1$ (multiresist drug) [77].

\subsection{Transcriptomics in Improving and Evaluating the Efficiency of Ecological Biotechnologies-Solution Approach}

The changes in gene expression and transcriptomic profiles of living organisms can serve as complementary information for developing NBSs and evaluating methods. In one study, a mixture of microbial and molecular (RT-qPCR using host-specific primers for Bacteroidetes) diagnostics was used to evaluate the performance of NBS for the removal of fecal pollution from run-off in Gryteland stream catchment (Norway) [78]. The authors also studied the concentration of selected PPCPs. The obtained results showed that the NBS efficiently removed the fecal pollution, but not the residues of PPCPs. What is more, the molecular approach allowed the non-human origins of pollution in faecal contamination to be distinguished from human origins, both of which were dependent on the season and environmental conditions. Generally, the human marker dominated and had a strong positive correlation with detected PPCPs.

RT-qPCR has also been used with DGGE and HTS-based bacterial community analysis to establish the efficiency of surface-flow CW (wetland park near Halmstad, Sweden), dominated by the vegetation of Phragmites australis and Typha latifolia, in terms of antibiotics removal and the influence of antibiotics on the detection of ARGs in CWs [79]. The RT-qPCR assay included the following ARGs: tet $A$ and tetB, ermB, sulI, dfrA1 (trimethoprim), qnrS (quinolone) and vanB (vancomycin), and intI1. The results demonstrated that neither antibiotics nor the water treatment system had any significant influence on bacterial community structure or ARG abundance. Low levels of ARG expression were observed in the studied sites, indicating that the ARGs that were present were carried by indigenous microorganisms. These results, together with chemical analysis of antibiotics concentrations, showed that CWs are suitable for the removal of studied compounds and they prevent the spread and increase of ARGs in the environment. A recent in vitro study examined the effect of climate change (i.e., higher temperatures) and exposure to a selected EDC (EE2) on the expression level of $v \operatorname{tg}$, er $\alpha$ (estrogen receptor $\alpha$ ), $\operatorname{er} \beta$ (estrogen receptor $\beta$ ), and $g r$ (glucocorticoid receptor) genes, responsible for reproduction processes, in Salmo trutta fario (brown trout) liver [80]. The expression was studied using RT-qPCR and expression profiling. A strong correlation was identified between temperature and gene expression, with higher temperatures in the presence of EDCs being associated with higher expression. Other studies have examined the adaptation of Oncorhynchus tshawytscha (chinook salmon) in response to changes in temperature and pesticide contamination (bifenthrin). The study examined the expression of the gnrh2 gene (brain gonadotropin releasing hormone receptor), $d r 2 a$ gene (dopamine receptor $2 \mathrm{~A}$ ), and $g h 1$ gene (growth hormone) in fry brain and alevin head tissues using qPCR [81]. Significant changes in gnrh 2 and $g h 1$ expression were observed, indicating that both higher temperature and pesticide use can potentially disrupt hormonal and signaling pathways. Other studies examined the effect of mild temperature increase and presence of benzophenone, a compound which is widely used in ultraviolet filters, on the expression of ecr, inr and met (genes related to the endocrine system); cyp4d2, cyp6b7, gst d6, gst o1, and mrp-1 (genes responsible for detoxification mechanisms); and hsp22, hsp27, hsp 70, hypu, and gp93 (stress response) in aquatic larvae of the freshwater macroinvertebrate Chironomus riparius 
(harlequin fly) using RT-qPCR [82]. It was found that even a slight difference of temperature can significantly alter the acute response of living organisms to contaminants and modify the expression of the studied genes.

Another method to evaluate the abundance of selected transcripts is NanoString nCounter ${ }^{\circledR}$. Although the system is similar to the qPCR technique, it allows the abundance of more than one gene in the same mixture to be evaluated using color-coded barcodes and does not require the conversion of mRNA to cDNA [83]. The technique was used for biomonitoring studies in the Great Lakes region, USA. The data were used to identify seasonal changes in CEC concentration, plasma Vtg concentration, morphometric pathology, and transcript abundance of selected genes ar $\beta$ (androgen receptor); chg (choriogenin); $\operatorname{er} \alpha, \operatorname{er} \beta 1$ and $\operatorname{er} \beta 2$ (estrogen receptors) and $v \operatorname{tg}$ in wild fish: Catostomus commersonii (white sucker), Micropterus salmoides (largemouth bass), and Micropterus dolomieu (smallmouth bass) in selected sampling sites [84]. It was found that the expression of the vtg and estrogen receptors were positively correlated with testicular oocyte severity in M. salmoides and M. dolomieu, but no testicular oocytes were formed in C. commersonii. The results highlight the importance of measuring several indicators, correlation analysis and using a diversity of organisms when studying the endocrine-disrupting abilities of CECs.

Another alternative for single qPCR reactions is based on the use of microarray analysis, which allows tens of thousands of mRNA transcripts to be measured simultaneously. Zebrafish microarray analysis was used to perform efficient surrogate monitoring, using Danio rerio as a model organism, as part of the National Water Pollution Control and Management Project conducted in the Liao River basin of China [85]. This genome-wide transcriptional profiling method was preceded by the extraction of RNA from fish liver tissues. The analysis of differentially expressed genes identified endocrine disruption and genotoxic and potential immunotoxin effects. Additionally, the comparison of the transcriptomic profiles of the sampled river surface water and the profiles of the model compounds indicate that pollutant patterns can be identified based on the toxic mechanism.

\section{Proteomic Methods in CEC Studies}

\subsection{Proteomics in the Monitoring of CEC Threats to Freshwater Ecosystems and Analysis of Cause-Effect Relationships-Assessment Approach}

Although information can be gained about transcription processes from analyses of the expression of certain genes, more accurate analyses of response to stress can be obtained using data on protein translation and activity. Hence, proteomics is a powerful tool that can be used to understand and evaluate the effect of CECs on the biota and their mode of action in the aquatic environment. However, there is only limited number of examples where proteomics have been applied in extensive field monitoring studies, which could be possibly employed in ecohydrological approach.

Regarding the impact of CECs on wild organisms, Bebianno et al. [86] used a proteomic approach for the assessment of the response of freshwater clam Corbicula fluminea to effluent from a psychiatric hospital containing a complex mixture of 25 pharmaceuticals. After 1-day exposure, the authors observed an increase in the abundance of structural proteins and calreticulin, as well as proliferation of cell nuclear antigen, $\mathrm{T}$ complex protein 1 and aldehyde dehydrogenase, alcohol dehydrogenase, and phosphogluconate dehydrogenase. Since the studied proteins were very sensitive to CEC exposure, they could be more useful biomarkers for standard ecotoxicological bioassays than genomic markers, such as changes in DNA sequences.

Another example of a study where a proteomic approach was used for ecotoxicological assessment was by Riva et al. [87], in which the protein expression profiles of gills of Dreissena polymorpha (zebra mussel) were analyzed using 2-DE and de novo sequencing using MALDI TOF/TOF tandem mass spectrometry after 7 days of exposure to triclosan (TCS). The obtained results showed that TCS caused substantial changes in the expression profiles of proteins, especially those involved in calcium binding or stress response. Both described studies showed that the proteomic approach is a powerful 
tool for investigating cellular responses of aquatic organism exposed to CECs; however, no long-term background data about hydrological conditions were presented.

De Maio et al. [38] used Western blotting to examine the influence of EDCs on the spermatogenesis of $P$. bergeri. It was found that the enzymes PARP1 and PARP2, known to play a role in the conservation of DNA integrity, demonstrate higher activity during periods of active spermatogenesis and high exposure to pollutants in rivers.

Protein mixtures can also be studied using shotgun proteomics, allowing a direct analysis of the protein profile within the mixture. Simmons et al. [88] used this approach to study the influence of PPCPs present in the treated WWTP effluents entering Cootes Paradise Marsh, a wetland at the western end of Lake Ontario, USA, on wild and caged C. auratus. Untargeted shotgun proteomics analysis found that effluent enriched with PPCPs significantly up- or down-regulated the expression of 36 proteins in caged male fish and 64 proteins in wild fish. By combining proteomics and metabolomics, it can be seen that exposure to PPCPs can affect the health of wild fish populations in wetlands.

\subsection{Proteomics in Improvement and Evaluation of Ecological Biotechnologies Efficiency—Solution Approach}

Proteomics can also be used to identify the mechanisms of resistance of plants used in constructed wetlands (CWs) to CECs and in this way help to optimize and select the biological elements of water treatment systems. Cyperus alternifolius (umbrella papyrus) has been considered as an efficient plant for phytoremediation purposes. The changes in protein expression following exposure to pharmaceuticals were measured using 2-DE-MALDI TOF/TOF tandem mass spectrometry [89]. The analysis revealed that the applied mixture of pharmaceuticals altered the expression of 19 proteins known to be functionally involved in various metabolic processes, particularly photosynthesis and energy metabolism. The authors conclude that the regulated proteins may favor the degradation of pharmaceuticals in CW. These results confirmed the processes underlying the tolerance of selected plants to CECs and showed that $C$. alternifolius is a good candidate for phytoremediation of environmental matrices contaminated with CECs. However, the precise role of detected proteins remains unknown and needs further investigation.

In contrast to other proteomic methods, label-free quantitative analysis measures the relative amounts of studied proteins and does not require the use of a stable isotope label for quantification [90]. A similar proteomic approach was used together with whole genome sequencing to characterize novel genetic markers for BPA degradation [91]. The Sphingomonas spp. BiD32 strain, which was isolated from activated sludge, was exposed to BPA in vitro conditions. The results revealed changes in the expression of 184 proteins in the presence of BPA. Additionally, a novel enzyme, p-hydroxybenzoate hydroxylase, was described as a possible marker for BPA degradation in the environment.

\section{Possibilities and Limitations-The Need for Further Research}

The potential use of molecular tools in ecohydrological research remains not fully realized. Most of the described articles (Table 1) do not refer to Ecohydrology directly and only a small fraction of ecohydrological research takes advantage of molecular analysis. This review provides examples of studies that could be potentially employed and integrated into either assessment of the environment quality or solution approaches (Figure 1). Most of the methods described in this review are used in ecotoxicological studies and studies on the development of ecological biotechnologies for water treatment improvement (e.g., constructed wetlands). On the other hand, the Ecohydrology-oriented studies do not fully exploit the potential of the molecular tools: most studies focus on phenotypic traits of organisms and their responses to prevailing hydrological conditions. A detailed understanding of the underlying water-biota interactions in terms of CECs effects on molecular level (dual regulation) is still missing. Hydrological and ecological approaches (e.g., biodiversity) are often not included in studies, being described separately. Thus, the integration of molecular tools into ecohydrological studies on CECs is necessary to provide detailed knowledge on the effects those compounds can exert and the processes leading to these outcomes. 
Table 1. The studies on the use of different molecular tools for the ecotoxicological assessment.

\begin{tabular}{|c|c|c|c|c|}
\hline Level & Studied CEC & Aim of the Study & Molecular Approach & Source \\
\hline \multirow{14}{*}{ DNA } & mixed pollutants (water from irrigation drainage) & $\begin{array}{l}\text { improvement of ecotoxicological assessment } \\
\text { using a battery of bioassays }\end{array}$ & total DNA quantification using fluorimetry & {$[44]$} \\
\hline & $\begin{array}{l}\text { pharmaceuticals (water form Madrid community } \\
\text { rivers) }\end{array}$ & $\begin{array}{l}\text { evaluation of photo-Fenton treatment for the } \\
\text { removal of pharmaceuticals }\end{array}$ & total DNA quantification using fluorimetry & [56] \\
\hline & $\begin{array}{l}\text { mixed pollutants (samples from wastewater, surface } \\
\text { waters, potable water) }\end{array}$ & $\begin{array}{l}\text { monitoring of water sources toxicity using } \\
\text { sensitive molecular tools }\end{array}$ & comet assay & {$[43]$} \\
\hline & $\begin{array}{l}\text { EDCs i.e., estrone, estradiol, EE2, BPA and } \\
\text { diethylstilbestrol }\end{array}$ & $\begin{array}{l}\text { evaluation of possible exposure to EDCs and } \\
\text { their effects on endocrine system of male } C \text {. } \\
\text { auratus using an integrated approach }\end{array}$ & comet assay & [40] \\
\hline & $\begin{array}{l}\text { EDCs i.e., EE2, sulfamethoxazole, atenolol, ibuprofen; } \\
\text { BPA and caffeine (Dalong Lake in Xuzhou) }\end{array}$ & $\begin{array}{l}\text { biomonitoring and ecotoxicological assessment } \\
\text { of the selected compounds on C. carassius }\end{array}$ & comet assay & [41] \\
\hline & ARGs & $\begin{array}{l}\text { determination of ARGs occurrence along the } \\
\text { studied section of Pilica river }\end{array}$ & PCR & [45] \\
\hline & ARGs & $\begin{array}{l}\text { determination of ARGs occurrence in } \\
\text { wastewater effluent }\end{array}$ & PCR & [46] \\
\hline & ARGs & $\begin{array}{l}\text { determination of ARGs occurrence in a } \\
\text { microcosm of constructed wetlands }\end{array}$ & PCR & [57] \\
\hline & $\begin{array}{l}\text { antibiotics (sulfonamides, } \beta \text {-lactam antibiotics, } \\
\text { tetracycline) }\end{array}$ & $\begin{array}{l}\text { determination of seasonal changes of the } \\
\text { abundance of ARG in freshwater reservoirs }\end{array}$ & qPCR & [47] \\
\hline & ARGs & $\begin{array}{l}\text { determination of the occurrence of ARs, } \\
\text { and ARGs in a surface water system subjected } \\
\text { to the discharge of treated WWTPs }\end{array}$ & qPCR & [48] \\
\hline & ARGs & $\begin{array}{l}\text { determination of the performance of an } \\
\text { ecological reservoir on mitigating antibiotics } \\
\text { and ARGs }\end{array}$ & qPCR & [58] \\
\hline & PFOA & $\begin{array}{l}\text { determination of the impact of the discharge of } \\
\text { a fluoropolymer plant on the macrobenthic } \\
\text { community }\end{array}$ & AFLP & [17] \\
\hline & mixed pollutants (water from Yangtze River, China) & $\begin{array}{l}\text { determination of the effect of drinking water } \\
\text { sources on thyroid-disrupting activities based } \\
\text { on African green monkey kidney fibroblast }\end{array}$ & reporter gene assay & [13] \\
\hline & $\begin{array}{l}\text { EDCs (samples from WWTPs, drinking water } \\
\text { treatment plant and river in the area of Paris) }\end{array}$ & $\begin{array}{l}\text { determination of thyroidal and estrogenic } \\
\text { activity of EDCs in different water supplies }\end{array}$ & reporter gene assay & [49] \\
\hline
\end{tabular}


Table 1. Cont.

\begin{tabular}{|c|c|c|c|c|}
\hline Level & Studied CEC & Aim of the Study & Molecular Approach & Source \\
\hline & $\begin{array}{l}\text { EDCs (samples from Upper Mississippi River in } \\
\text { Minnesota, USA) }\end{array}$ & $\begin{array}{l}\text { determination of genetic diversity of under } \\
\text { exposure of EDCs }\end{array}$ & microsatellites & [50] \\
\hline & EDCs i.e., caffeine, acetaminophenon, diclofenac & $\begin{array}{l}\text { determination of the effect of selected EDCs on } \\
\text { the biodiversity of river biofilm and selection } \\
\text { of archaeal communities as significant } \\
\text { organisms for ecotoxicological assessment }\end{array}$ & DGGE & [51] \\
\hline & pharmaceuticals & $\begin{array}{l}\text { determination of the persistence of } \\
\text { pharmaceuticals in incubations containing } \\
\text { riverine bacterio-plankton }\end{array}$ & DGGE & [59] \\
\hline & ciprofloxacine & $\begin{array}{l}\text { determination of the effect of ciprofloxacine on } \\
\text { bacterial wetland communities }\end{array}$ & DGGE & [60] \\
\hline & perchlorate & $\begin{array}{l}\text { determination of wetland bioreactor } \\
\text { performance and abundance of autochthonous } \\
\text { perchlorate-reducing bacteria }\end{array}$ & DGGE and sequencing & [61] \\
\hline & radionuclides & $\begin{array}{l}\text { determination of the impact of radiation } \\
\text { exposure on the genetic diversity of the } \\
\text { freshwater crustacean } A \text {. aquaticus }\end{array}$ & HTS & [54] \\
\hline & PFOA & $\begin{array}{l}\text { assessment of the changes in microbial } \\
\text { community composition and structure upon } \\
\text { PFOA exposure }\end{array}$ & HTS & [52] \\
\hline & BDE-99 & $\begin{array}{l}\text { determination of the effect of biochar on the } \\
\text { anaerobic degradation of BDE- } 99 \text { by archaea }\end{array}$ & HTS, FISH & [62] \\
\hline & disinfectants & $\begin{array}{l}\text { determination of the influence of } \\
\text { benzalkonium chlorides on the proliferation of } \\
\text { antibiotic resistant bacteria in the environment }\end{array}$ & HTS & [53] \\
\hline & TCBPA (E-waste processing facility) & $\begin{array}{l}\text { analysis of the microbial communities in river } \\
\text { sediments for anaerobic digestion of TCBPA }\end{array}$ & HTS & [63] \\
\hline & antibiotics (quinolones, sulfonamides, macrolides) & $\begin{array}{l}\text { determination of the relationship between the } \\
\text { removal efficiency of CECs and bacterial } \\
\text { community structure }\end{array}$ & HTS & [64] \\
\hline & polybrominated diphenyl ether & $\begin{array}{l}\text { determination of anaerobic degradation of } \\
\text { polybrominated diphenyl ether in marine and } \\
\text { freshwater sediments }\end{array}$ & T-RFLP, HTS, qPCR & [65] \\
\hline & microcystins & $\begin{array}{l}\text { identification of bacterial strains capable of } \\
\text { microcystin degradation }\end{array}$ & HTS & [66] \\
\hline
\end{tabular}


Table 1. Cont.

\begin{tabular}{|c|c|c|c|c|}
\hline Level & Studied CEC & Aim of the Study & Molecular Approach & Source \\
\hline \multirow{13}{*}{ RNA } & microplastics & $\begin{array}{l}\text { evaluation of the role of microplastic particles } \\
\text { in bacterial abundance and the presence of int } 1 \\
\text { gene, }\end{array}$ & ARISA, qPCR & [55] \\
\hline & EDCs & $\begin{array}{l}\text { determination of the effect of EDCs on } \\
\text { vitellogenin synthesis in freshwater amphipod } \\
\text { G. fossarum }\end{array}$ & RT-PCR & {$[68]$} \\
\hline & $\begin{array}{l}\text { EDCs i.e., 4-t-octylphenol, nonylphenol, BPA, } \\
\text { estradiol, EE2 }\end{array}$ & $\begin{array}{l}\text { determination of the effect of selected steroidal } \\
\text { and phenolic EDCs on H. leucisculus }\end{array}$ & RT-qPCR & [69] \\
\hline & mixed pollutants (Guangzhou River, China) & $\begin{array}{l}\text { evaluation of } \mathrm{ABM} \text { and molecular tools for } \\
\text { estimating effects of mixed pollutants on } M \text {. } \\
\text { abei }\end{array}$ & semi-quantitative RT-PCR & [71] \\
\hline & mixed pollutants (i.e., PPCPs and pharmaceticals) & $\begin{array}{l}\text { evaluation of the use of an } \mathrm{ABM} \text { for an early } \\
\text { detection of trace contaminants }\end{array}$ & RT-qPCR & [70] \\
\hline & $\begin{array}{l}\text { mixed pollutants (urbanized river rich receiving } \\
\text { wastewater effluents) }\end{array}$ & $\begin{array}{l}\text { determination of the environmental } \\
\text { monitoring programs and characterization of } \\
\text { the response of E. caerulum to contaminants }\end{array}$ & RT-qPCR & [72] \\
\hline & $\begin{array}{l}\text { mixed pollutants (exposure to contaminated } \\
\text { sediments from river Po, Italy) }\end{array}$ & $\begin{array}{l}\text { determination of the use of selected gene } \\
\text { expression profiles of } B \text {. plebejus for an } \\
\text { indicator of long-term sediment exposure }\end{array}$ & RT-qPCR & [73] \\
\hline & benzyl butyl phthalate & $\begin{array}{l}\text { determination of the toxicity of benzyl butyl } \\
\text { phthalate on C. riparius aquatic larvae }\end{array}$ & RT-PCR & [74] \\
\hline & psychoactive drugs mixture & $\begin{array}{l}\text { determination of selected parameters of } L \text {. } \\
\text { minor and C. fluminea for sensible and early } \\
\text { indicators of exposure to drugs }\end{array}$ & RT-qPCR & [77] \\
\hline & pharmaceuticals, PPCPs & $\begin{array}{l}\text { determination of NBS (CW) performance for } \\
\text { removal of different contaminants from } \\
\text { catchment run-off }\end{array}$ & RT-qPCR & [78] \\
\hline & EE2 & $\begin{array}{l}\text { analysis of the potential interaction between } \\
\text { ambient water temperature and the Vtg } \\
\text { production induced by EE2 }\end{array}$ & RT-qPCR & [80] \\
\hline & bifenthrin & $\begin{array}{l}\text { determination of the potential interaction } \\
\text { between temperature and pesticide exposure } \\
\text { on salmonid development }\end{array}$ & RT-qPCR & [81] \\
\hline & benzophenone & $\begin{array}{l}\text { evaluation of the response and adaptation of } \\
\text { larvae } C \text {. riparius to the contamination and } \\
\text { different temperatures }\end{array}$ & RT-qPCR & [82] \\
\hline
\end{tabular}


Table 1. Cont.

\begin{tabular}{|c|c|c|c|c|}
\hline Level & Studied CEC & Aim of the Study & Molecular Approach & Source \\
\hline & mixed pollutants (sample from HunRiver, China) & $\begin{array}{l}\text { determination of the use of transcriptomic } \\
\text { profiles of } D \text {. rerio as an indicator for } \\
\text { contaminated surface water }\end{array}$ & microarray RNA analysis & [85] \\
\hline & mixed pollutants (three rivers in Galicia, Spain) & $\begin{array}{l}\text { improvement of ecotoxicological bioassays } \\
\text { using a battery of bioassays and comparative } \\
\text { studies in natural populations of the benthic } \\
\text { larvae of C. riparius }\end{array}$ & hsp70 gene expression & [75] \\
\hline & $\begin{array}{l}\text { mixed pollutants (emphasis on EDCs (samples from } \\
\text { Great Lakes Basin, USA) }\end{array}$ & $\begin{array}{l}\text { seasonal biomonitoring of transcriptomic } \\
\text { profiles changes in C. comersonii, M. salmonides } \\
\text { and } M \text {. dolomieu and comparison of relative } \\
\text { sensitivity of chosen organisms and } \\
\text { biomarkers }\end{array}$ & $\begin{array}{l}\text { quantitative transcript abundance assay } \\
\text { [83] }\end{array}$ & [84] \\
\hline \multirow{2}{*}{ DNA and RNA } & microcystins & $\begin{array}{l}\text { determination of the influence of biotic and } \\
\text { abiotic factors on cyanobacterial blooms }\end{array}$ & RT-qPCR and HTS & [76] \\
\hline & antibiotics & $\begin{array}{l}\text { determination of CW performance for removal } \\
\text { of antibiotics and their influence on ARG } \\
\text { spread in the environment }\end{array}$ & RT-qPCR, DGGE and HTS & [79] \\
\hline \multirow{5}{*}{ protein } & EDCs (effluent from psychiatric hospital) & $\begin{array}{l}\text { ecotoxicological characterization and selection } \\
\text { of suitable bioindicator C. fluminea for hospital } \\
\text { effluents }\end{array}$ & 2-DE LC MS/MS & [86] \\
\hline & TCS & $\begin{array}{l}\text { determination of the effect of TCS on the } \\
\text { metabolism of } D \text {. polymorpha }\end{array}$ & 2-DE and de novo sequencing & [87] \\
\hline & pharmaceuticals & $\begin{array}{l}\text { determination of stress-related molecular } \\
\text { mechanisms in C. alternifolius in constructed } \\
\text { wetlands }\end{array}$ & 2-DE-MALDI TOF/TOF MS & [89] \\
\hline & BPA & $\begin{array}{l}\text { identification of novel markers for BPA } \\
\text { degradation in the environment }\end{array}$ & label-free quantitation proteomics & [91] \\
\hline & PPCPs & assessment of the impact of PPCPs on wild fish & shotgun proteomic approach & {$[88]$} \\
\hline DNA and protein & EDCs (Sarno River and Matese Lake) & $\begin{array}{l}\text { biomonitoring of seasonal variations of } \\
\text { molecular DNA damage markers in } P \text {. bergeri }\end{array}$ & $\begin{array}{l}\text { DNA profiling and PARP enzymes activity } \\
\text { evaluation }\end{array}$ & {$[38]$} \\
\hline
\end{tabular}


The majority of the described articles are based on DNA analysis, because those methods are easy, have high throughput and are sufficient to draw some general conclusions. The use of environmental genetics and genomics provides an opportunity to examine the genetic variations between populations of organisms. Those methods allow susceptible genes to be identified and the response of organisms to stress factors to be evaluated. They also provide an insight into the key regulatory genes and pathways using comparative genomics with model organisms [10]. However, results obtained using DNA-based methods can often be misleading, because some regulatory processes can take place at the transcription and translation level. Consequently, there is a need to focus more on the significance of RNA and especially proteins, because they provide a clearer view of the true metabolic response of living organisms to CECs. Therefore, modern studies should turn more to activity-focused approaches based on transcriptomic and proteomic analysis [15].

Analyses based on mRNA provide a more accurate determination of actively-expressed genes in different cells and tissues, thus allowing more accurate and representative analysis. The expression profiles of selected genes give a reliable indication of the physiological response of living organisms to stress factors such as CECs. Proteomics has been used less extensively in recent years following the introduction of more sophisticated and high-cost analyses, such as those involving the separation and identification of the target proteins and the study of their function [20]. However these methods are more labor intensive and difficult, as both RNA and proteins are less stable than DNA. Additionally, proteomic approaches are more expensive and need highly experienced staff.

The integration of genomic, transcriptomic and proteomic profiling in ecohydrological studies would give a better view of the biological responses to CECs stress in the environment. It is likely that environmental studies will increasingly use approaches based on analyzing protein expression profiles and their response to environmental stresses, thus providing a clearer insight into the cellular mechanisms and function of some proteins and utilization of CECs at the cellular level [20]. Often the selection of a molecular approach is crucial because even though some methods can be relatively cheap and easy, they are not reliable enough. It is also essential to distinguish the effect of CECs and other factors such as geographical barriers or environmental continuity, which can affect the appearance of genetic changes. Thus, in compliance with the ecohydrological approach, the integration of chemical and biomarkers assays can be used to comprehensively determine the true risk to the freshwater organisms in contaminated sites (e.g., behavioral changes, reproduction disturbance).

The presented data also shows the importance of the correct selection of experimental conditions (e.g., laboratory or field studies; duration of an experiment) and the interactions between the different contaminants (e.g., organic contaminants and ARGs) in the evaluation of the response of living organisms to CECs. It is worth noting that monitoring the molecular changes under real conditions can demonstrate how organisms respond in the natural environment, whereas the obtained results might be significantly biased in artificial laboratory systems. Field studies are, however, more complicated because of the necessity to consider the interactions between plants, animals, topography, and climate, which can alter the environment significantly. It is also more challenging to develop standardized methods for field studies: under laboratory conditions, experiments can be easily optimized and repeated. For example, microcosms experiments are closed homogenous systems that provide detailed and statistically valid data on studied processes, however, the results do not always refer to reality. Hence, both field and lab studies should be integrated in order to develop cooperative projects [92].

Therefore, we wish to emphasize the greater need to incorporate molecular tools in future studies of the ecohydrological approach for CEC management. As the global climate change has been influencing the water cycle and the fates and effects of CECs on biocenosis, it is essential to study the correlations between hydrological parameters and responses of biota at DNA, RNA and protein levels, since most existing studies describe them separately. 


\section{Conclusions}

This review highlights the important role played by molecular tools in the assessment and solution approach (Figure 1) for the management and removal of CECs from freshwater environments. Although the studies use a range of DNA analyses, the most common are those based on genotoxicity assessment, DNA quantification, the assessment of DNA impairments, PCR and qPCR of selected DNA fragments, and genetic diversity assessment using various methods (e.g., microsatellites, DGGE, HTS, T-RFLP, FISH, AFLP, and ARISA-PCR). These techniques are nowadays robust and are considered essential for a range of tasks: monitoring CEC distribution in the environment, identifying CEC-disrupting activities on ecosystem functions, verification of the negative effect of CECs on freshwater ecosystem biodiversity, determination of organism tolerance to CECs, and the development of NBSs and effectiveness at CEC removal and toxic effect mitigation. The gathered data shows that the response to CECs of organisms inhabiting different freshwater ecosystems is dependent on their species characteristics, time of exposure, sample type (water or sediment), and geographical distance from contaminated sites.

It is also implied that the data from genetic analysis alone is not sufficient to assess the actual effects of CECs on living organisms and that the RNA analyses described herein give more reliable information for the identification of stressors and their threshold values for stress response. Additionally, such transcriptome profiling also enables the verification of abiotic-biotic interactions (e.g., seasonal changes, the synergistic effect of climate change and CEC contamination), natural and anthropogenic processes causing harmful effects in the environment, and evaluation of NBS efficiency for the removal and prevention of CEC spread. Although substantially less research has been performed regarding protein profiling, proteomics has also been employed in ecotoxicological studies e.g., for the development of novel degradation markers and the determination of proteins responsible for the resistance of plant to CECs.

The integration of genomics, transcriptomics, proteomics and other analyses (i.e., physicochemical approaches) provides an interdisciplinary view on the response of biotic elements of the ecosystems to CECs. It is important to highlight that the molecular tools presented in this review are often more sensitive and suitable for ecohydrological approaches than the traditional methods used in Hydrobiology. This is in line with the principles of Ecohydrology, which emphasize the importance of multiple indicator measurements and correlation analysis in determining the dual regulation phenomenon. In addition, a great number of the described analyses focus on the development of efficient and cost-effective NBSs (i.e., CWs) to successfully remove CECs from freshwater ecosystems. In conclusion, there is a growing need to employ more innovative and state-of-the-art molecular methods, either as main or complementary modes of analysis in ecohydrological studies.

Author Contributions: Conceptualization, writing—original draft preparation, writing—review and editing-E.M. and M.U.; visualization-E.M.; supervision-M.U. All authors have read and agreed to the published version of the manuscript.

Funding: This research was funded by the European Structural and Investment Funds, OP RDE-funded project 'CHEMFELLS4UCTP' (No. CZ.02.2.69/0.0/0.0/17_050/0008485) and by The Council of the National Science Centre in Poland ETIUDA 7- funded project "Cucurbits and their plant secondary metabolites as stimulators of biological soil remediation contaminated with phenoxy herbicides" (No. 2019/32/T/NZ9/00403).

Conflicts of Interest: The authors declare no conflict of interest.

\section{References}

1. Smital, T. Acute and Chronic Effects of Emerging Contaminants. In Emerging Contaminants from Industrial and Municipal Waste; Springer: Berlin/Heidelberg, Germany, 2008; pp. 105-142.

2. Rosenfeld, P.E.; Feng, L.G.H. Emerging Contaminants. In Risks of Hazardous Wastes; Elsevier: Amsterdam, The Netherlands, 2011; pp. 215-222.

3. Sauvé, S.; Desrosiers, M. A review of what is an emerging contaminant. Chem. Cent. J. 2014, 8, 15. [CrossRef] [PubMed] 
4. Zalewski, M. Ecohydrology-The Scientific Background to use Ecosystem Properties as Management Tools Toward Sustainability of Water Resources. Ecol. Eng. 2000, 16, 1-8. [CrossRef]

5. Zalewski, M. Ecohydrology and Hydrologic Engineering: Regulation of Hydrology-Biota Interactions for Sustainability. J. Hydrol. Eng. 2014, 20, A4014012. [CrossRef]

6. Paszko, T.; Muszyński, P.; Materska, M.; Bojanowska, M.; Kostecka, M.; Jackowska, I. Adsorption and degradation of phenoxyalkanoic acid herbicides in soils: A review. Environ. Toxicol. Chem. 2016, 35, 271-286. [CrossRef]

7. Rheinheimer dos Santos, D.; Monteiro de Castro Lima, J.A.; Paranhos Rosa de Vargas, J.; Camotti Bastos, M.; Santanna dos Santos, M.A.; Mondamert, L.; Labanowski, J. Pesticide bioaccumulation in epilithic biofilms as a biomarker of agricultural activities in a representative watershed. Environ. Monit. Assess. 2020, 192, 381. [CrossRef]

8. Schiedek, D.; Sundelin, B.; Readman, J.W.; Macdonald, R.W. Interactions between climate change and contaminants. Mar. Pollut. Bull. 2007, 54, 1845-1856. [CrossRef]

9. Pauls, S.; Alp, M.; Bálint, M.; Bernabò, P.; Čiampor, F., Jr.; Čiamporová-Zat'ovičová, Z.; Finn, D.; Kohout, J.; Leese, F.; Lencioni, V.; et al. Integrating molecular tools into freshwater ecology: Developments and opportunities. Freshw. Biol. 2014, 59, 1559-1576. [CrossRef]

10. Schwartz, D.A. Environmental genomics: A key to understanding biology, pathophysiology and disease. Hum. Mol. Genet. 2004, 13, R217-R224. [CrossRef]

11. Bej, A.K.; Mahbubani, M.H. Applications of the polymerase chain reaction in environmental microbiology. Genome Res. 1992, 1, 151-159. [CrossRef]

12. Bagchi Bhattacharjee, G.; Paul Khurana, S.M. In Vitro Reporter Assays for Screening of Chemicals That Disrupt Androgen Signaling. J. Toxicol. 2014, 2014, 1-7. [CrossRef]

13. Hu, X.; Shi, W.; Zhang, F.; Cao, F.; Hu, G.; Hao, Y.; Wei, S.; Wang, X.; Yu, H. In vitro assessment of thyroid hormone disrupting activities in drinking water sources along the Yangtze River. Environ. Pollut. 2013, 173, 210-215. [CrossRef] [PubMed]

14. Green, S.J.; Leigh, M.B.; Neufeld, J.D. Denaturing Gradient Gel Electrophoresis (DGGE) for Microbial Community Analysis. In Handbook of Hydrocarbon and Lipid Microbiology; Springer: Berlin/Heidelberg, Germany, 2010; pp. 4137-4158.

15. Bell, T.H.; Joly, S.; Pitre, F.E.; Yergeau, E. Increasing phytoremediation efficiency and reliability using novel omics approaches. Trends Biotechnol. 2014, 32, 271-280. [CrossRef] [PubMed]

16. Hata, D.J. Molecular Methods for Identification and Characterization of Acinetobacter spp. In Molecular Diagnostics; Elsevier: Amsterdam, The Netherlands, 2010; pp. 313-326.

17. Rusconi, M.; Marziali, L.; Stefani, F.; Valsecchi, S.; Bettinetti, R.; Mazzoni, M.; Rosignoli, F.; Polesello, S. Evaluating the impact of a fluoropolymer plant on a river macrobenthic community by a combined chemical, ecological and genetic approach. Sci. Total Environ. 2015, 538, 654-663. [CrossRef] [PubMed]

18. Huber, D.; Voith von Voithenberg, L.; Kaigala, G.V. Fluorescence in situ hybridization (FISH): History, limitations and what to expect from micro-scale FISH? Micro Nano Eng. 2018, 1, 15-24. [CrossRef]

19. Fisher, M.M.; Triplett, E.W. Automated approach for ribosomal intergenic spacer analysis of microbial diversity and its application to freshwater bacterial communities. Appl. Environ. Microbiol. 1999, 65, 4630-4636. [CrossRef] [PubMed]

20. Chu, X.; Hu, J.; Ong, S.L. Application of proteomics in environmental science. Front. Environ. Sci. Eng. China 2009, 3, 393-403. [CrossRef]

21. Clarivate Analytics Web of Science. Available online: www.webofknowledge.com (accessed on 30 April 2020).

22. Kessler, J.; Dawley, D.; Crow, D.; Garmany, R.; Georgel, P.T. Potential Health Risks Linked to Emerging Contaminants in Major Rivers and Treated Waters. Water 2019, 11, 2615. [CrossRef]

23. Guerrero-Estevez, S.M.; Lopez-Lopez, E. Effects of endocrine disruptors on reproduction in viviparous teleosts with intraluminal gestation. Rev. Fish Biol. Fish. 2016, 26, 563-587. [CrossRef]

24. Kudlak, B.; Szczepanska, N.; Owczarek, K.; Mazerska, Z.; Namiesnik, J. Revision of Biological Methods for Determination of EDC Presence and Their Endocrine Potential. Crit. Rev. Anal. Chem. 2015, 45, 191-200. [CrossRef]

25. Bahamonde, P.A.; Munkittrick, K.R.; Martyniuk, C.J. Intersex in teleost fish: Are we distinguishing endocrine disruption from natural phenomena? Gen. Comp. Endocrinol. 2013, 192, 25-35. [CrossRef] 
26. Shenoy, K.; Crowley, P.H. Endocrine disruption of male mating signals: Ecological and evolutionary implications. Funct. Ecol. 2011, 25, 433-448. [CrossRef]

27. Liu, X.; Guo, X.; Liu, Y.; Lu, S.; Xi, B.; Zhang, J.; Wang, Z.; Bi, B. A review on removing antibiotics and antibiotic resistance genes from wastewater by constructed wetlands: Performance and microbial response. Environ. Pollut. 2019, 254. [CrossRef] [PubMed]

28. Singh, R.; Singh, A.P.; Kumar, S.; Giri, B.S.; Kim, K.-H. Antibiotic resistance in major rivers in the world: A systematic review on occurrence, emergence, and management strategies. J. Clean. Prod. 2019, 234, 1484-1505. [CrossRef]

29. Edwards, S.J.; Kjellerup, B. V Applications of biofilms in bioremediation and biotransformation of persistent organic pollutants, pharmaceuticals/personal care products, and heavy metals. Appl. Microbiol. Biotechnol. 2013, 97, 9909-9921. [CrossRef] [PubMed]

30. Fong, P.P.; Ford, A.T. The biological effects of antidepressants on the molluscs and crustaceans: A review. Aquat. Toxicol. 2014, 151, 4-13. [CrossRef] [PubMed]

31. Ncube, S.; Madikizela, L.M.; Chimuka, L.; Nindi, M.M. Environmental fate and ecotoxicological effects of antiretrovirals: A current global status and future perspectives. Water Res. 2018, 145, 231-247. [CrossRef]

32. Zur, J.; Pinski, A.; Marchlewicz, A.; Hupert-Kocurek, K.; Wojcieszynska, D.; Guzik, U. Organic micropollutants paracetamol and ibuprofen-toxicity, biodegradation, and genetic background of their utilization by bacteria. Environ. Sci. Pollut. Res. 2018, 25, 21498-21524. [CrossRef]

33. Capela, R.; Garric, J.; Costa Castro, L.F.; Santos, M.M. Embryo bioassays with aquatic animals for toxicity testing and hazard assessment of emerging pollutants: A review. Sci. Total Environ. 2020, 705. [CrossRef]

34. Blanton, M.L.; Specker, J.L. The hypothalamic-pituitary-thyroid (HPT) axis in fish and its role in fish development and reproduction. Crit. Rev. Toxicol. 2007, 37, 97-115. [CrossRef]

35. Xiong, J.-Q.; Kurade, M.B.; Jeon, B.-H. Can Microalgae Remove Pharmaceutical Contaminants from Water? Trends Biotechnol. 2018, 36, 30-44. [CrossRef]

36. Mankiewicz-Boczek, J. Application of molecular tools in Ecohydrology. Ecohydrol. Hydrobiol. 2012, 12, 165-170. [CrossRef]

37. Klein, A.H.; Ballard, K.R.; Storey, K.B.; Motti, C.A.; Zhao, M.; Cummins, S.F. Multi-omics investigations within the Phylum Mollusca, Class Gastropoda: From ecological application to breakthrough phylogenomic studies. Brief. Funct. Genom. 2019, 18, 377-394. [CrossRef]

38. De Maio, A.; Trocchia, S.; Guerriero, G. The amphibian Pelophylax bergeri (Gunther, 1986) testis poly(ADP-ribose) Polymerases: Relationship to endocrine disruptors during spermatogenesis. Ital. J. Zool. 2014, 81, 256-263. [CrossRef]

39. Collins, A.R. The Comet Assay for DNA Damage and Repair: Principles, Applications, and Limitations. Mol. Biotechnol. 2004, 26, 249-261. [CrossRef]

40. Yan, Z.; Lu, G.; Liu, J.; Jin, S. An integrated assessment of estrogenic contamination and feminization risk in fish in Taihu Lake, China. Ecotoxicol. Environ. Saf. 2012, 84, 334-340. [CrossRef]

41. Yu, H.; Cao, W. Assessment of pharmaceutical and personal care products (PPCPs) of Dalong Lake in Xuzhou by concentration monitoring and bio-effects monitoring process. Environ. Toxicol. Pharmacol. 2016, 43, 209-215. [CrossRef]

42. International Organization for Standardization. Water Quality-Determination of the Genotoxicity of Water and Waste Water Using the Umu-Test; ISO 13829:2000; ISO: Geneva, Switzerland, 2000.

43. Zegura, B.; Heath, E.; Cernosa, A.; Filipic, M. Combination of in vitro bioassays for the determination of cytotoxic and genotoxic potential of wastewater, surface water and drinking water samples. Chemosphere 2009, 75, 1453-1460. [CrossRef]

44. Luis Rodriguez-Gil, J.; Sebastian Sauto, J.S.; Gonzalez-Alonso, S.; Sanchez Sanchez, P.; Valcarcel, Y.; Catala, M. Development of cost-effective strategies for environmental monitoring of irrigated areas in Mediterranean regions: Traditional and new approaches in a changing world. Agric. Ecosyst. Environ. 2013, 181, 41-49. [CrossRef]

45. Koniuszewska, I.; Korzeniewska, E.; Harnisz, M.; Kiedrzyńska, E.; Kiedrzyński, M.; Czatzkowska, M.; Jarosiewicz, P.; Zalewski, M. The occurrence of antibiotic-resistance genes in the Pilica River, Poland. Ecohydrol. Hydrobiol. 2020, 20, 1-11. [CrossRef] 
46. Czatzkowska, M.; Harnisz, M.; Kiedrzyńska, E.; Kiedrzyński, M.; Koniuszewska, I.; Korzeniewska, E.; Szklarek, S.; Zalewski, M. Catchment scale analysis of occurrence of antibiotic resistance genes in treated wastewater. Ecohydrol. Hydrobiol. 2020, 20, 12-20. [CrossRef]

47. Son, D.; Aleta, P.; Park, M.; Yoon, H.; Cho, K.H.; Kim, Y.M.; Kim, S. Seasonal Changes in Antibiotic Resistance Genes in Rivers and Reservoirs in South Korea. J. Environ. Qual. 2018, 47, 1079-1085. [CrossRef] [PubMed]

48. Voigt, A.M.; Ciorba, P.; Döhla, M.; Exner, M.; Felder, C.; Lenz-Plet, F.; Sib, E.; Skutlarek, D.; Schmithausen, R.M.; Faerber, H.A. The investigation of antibiotic residues, antibiotic resistance genes and antibiotic-resistant organisms in a drinking water reservoir system in Germany. Int. J. Hyg. Environ. Health 2020, 224, 113449. [CrossRef] [PubMed]

49. Jugan, M.L.; Oziol, L.; Bimbot, M.; Huteau, V.; Tamisier-Karolak, S.; Blondeau, J.P.; Lévi, Y. In vitro assessment of thyroid and estrogenic endocrine disruptors in wastewater treatment plants, rivers and drinking water supplies in the greater Paris area (France). Sci. Total Environ. 2009, 407, 3579-3587. [CrossRef] [PubMed]

50. Miller, L.M.; Bartell, S.E.; Schoenfuss, H.L. Assessing the Effects of Historical Exposure to Endocrine-Active Compounds on Reproductive Health and Genetic Diversity in Walleye, a Native Apex Predator, in a Large Riverine System. Arch. Environ. Contam. Toxicol. 2012, 62, 657-671. [CrossRef] [PubMed]

51. Lawrence, J.R.; Zhu, B.; Swerhone, G.D.W.; Roy, J.; Tumber, V.; Waiser, M.J.; Topp, E.; Korber, D.R. Molecular and microscopic assessment of the effects of caffeine, acetaminophen, diclofenac, and their mixtures on river biofilm communities. Environ. Toxicol. Chem. 2012, 31, 508-517. [CrossRef]

52. Zhang, D.; Zhang, W.; Liang, Y. Bacterial community in a freshwater pond responding to the presence of perfluorooctanoic acid (PFOA). Environ. Technol. 2019, 1-11. [CrossRef] [PubMed]

53. Kim, M.; Weigand, M.R.; Oh, S.; Hatt, J.K.; Krishnan, R.; Tezel, U.; Pavlostathis, S.G.; Konstantinidis, K.T. Widely Used Benzalkonium Chloride Disinfectants Can Promote Antibiotic Resistance. Appl. Environ. Microbiol. 2018, 84. [CrossRef] [PubMed]

54. Fuller, N.; Ford, A.T.; Lerebours, A.; Gudkov, D.I.; Nagorskaya, L.L.; Smith, J.T. Chronic radiation exposure at Chernobyl shows no effect on genetic diversity in the freshwater crustacean, Asellus aquaticus thirty years on. Ecol. Evol. 2019, 9, 10135-10144. [CrossRef]

55. Eckert, E.M.; Di Cesare, A.; Kettner, M.T.; Arias-Andres, M.; Fontaneto, D.; Grossart, H.-P.; Corno, G. Microplastics increase impact of treated wastewater on freshwater microbial community. Environ. Pollut. 2018, 234, 495-502. [CrossRef]

56. Rodríguez-Gil, J.L.; Catalá, M.; Alonso, S.G.; Maroto, R.R.; Valcárcel, Y.; Segura, Y.; Molina, R.; Melero, J.A.; Martínez, F. Heterogeneous photo-Fenton treatment for the reduction of pharmaceutical contamination in Madrid rivers and ecotoxicological evaluation by a miniaturized fern spores bioassay. Chemosphere 2010, 80, 381-388. [CrossRef]

57. Nowrotek, M.; Kotlarska, E.; Łuczkiewicz, A.; Felis, E.; Sochacki, A.; Miksch, K. The treatment of wastewater containing pharmaceuticals in microcosm constructed wetlands: The occurrence of integrons (int1-2) and associated resistance genes (sul1-3, qacEA1). Environ. Sci. Pollut. Res. 2017, 24, 15055-15066. [CrossRef] [PubMed]

58. Li, P.; Wu, Y.; He, Y.; Zhang, B.; Huang, Y.; Yuan, Q.; Chen, Y. Occurrence and fate of antibiotic residues and antibiotic resistance genes in a reservoir with ecological purification facilities for drinking water sources. Sci. Total Environ. 2020, 707, 135276. [CrossRef] [PubMed]

59. Tappin, A.D.; Loughnane, J.P.; McCarthy, A.J.; Fitzsimons, M.F. Unexpected removal of the most neutral cationic pharmaceutical in river waters. Environ. Chem. Lett. 2016, 14, 455-465. [CrossRef]

60. Weber, K.P.; Mitzel, M.R.; Slawson, R.M.; Legge, R.L. Effect of ciprofloxacin on microbiological development in wetland mesocosms. Water Res. 2011, 45, 3185-3196. [CrossRef] [PubMed]

61. Krauter, P.; Daily, B.; Dibley, V.; Pinkart, H.; Legler, T. Perchlorate and Nitrate Remediation Efficiency and Microbial Diversity in a Containerized Wetland Bioreactor. Int. J. Phytoremediat. 2005, 7, 113-128. [CrossRef]

62. Yan, Y.; Ma, M.; Liu, X.; Ma, W.; Li, M.; Yan, L. Effect of biochar on anaerobic degradation of pentabromodiphenyl ether (BDE-99) by archaea during natural groundwater recharge with treated municipal wastewater. Int. Biodeterior. Biodegrad. 2017, 124, 119-127. [CrossRef]

63. Zhang, J.; Liu, S.; Li, L.; Ren, Y.; Feng, C.; Wei, C.; Li, Y.; Huang, Z. Anaerobic Dechlorination of Tetrachlorobisphenol A in River Sediment and Associated Changes in Bacterial Communities. Water Air Soil Pollut. 2017, 228, 78. [CrossRef] 
64. Shan, A.; Wang, W.; Kang, K.J.; Hou, D.; Luo, J.; Wang, G.; Pan, M.; Feng, Y.; He, Z.; Yang, X. The Removal of Antibiotics in Relation to a Microbial Community in an Integrated Constructed Wetland for Tail Water Decontamination. Wetlands 2020, 40. [CrossRef]

65. Wang, Y.F.; Zhu, H.W.; Wang, Y.; Zhang, X.L.; Tam, N.F.Y. Diversity and Dynamics of Microbial Community Structure in Different Mangrove, Marine and Freshwater Sediments During Anaerobic Debromination of PBDEs. Front. Microbiol. 2018, 9. [CrossRef]

66. Nájera, A.F.; Serwecińska, L.E.; Gagała-Borowska, I.; Jurczak, T.E.; Mankiewicz-Boczek, J.D. The characterization of a novel bacterial strain capable of microcystin degradation from the Jeziorsko reservoir, Poland: A preliminary study. Biologia 2017, 72. [CrossRef]

67. Snell, T.; Edge, S.; Morgan, M. Gene expression profiling in ecotoxicology. Ecotoxicology 2003, 12, 475-483. [CrossRef] [PubMed]

68. Xuereb, B.; Bezin, L.; Chaumot, A.; Budzinski, H.; Augagneur, S.; Tutundjian, R.; Garric, J.; Geffard, O. Vitellogenin-like gene expression in freshwater amphipod Gammarus fossarum (Koch, 1835): Functional characterization in females and potential for use as an endocrine disruption biomarker in males. Ecotoxicology 2011, 20, 1286-1299. [CrossRef] [PubMed]

69. Wang, S.; Zhu, Z.; He, J.; Yue, X.; Pan, J.; Wang, Z. Steroidal and phenolic endocrine disrupting chemicals (EDCs) in surface water of Bahe River, China: Distribution, bioaccumulation, risk assessment and estrogenic effect on Hemiculter leucisculus. Environ. Pollut. 2018, 243, 103-114. [CrossRef] [PubMed]

70. Quesada-Garcia, A.; Valdehita, A.; Torrent, F.; Villarroel, M.; Dolores Hernando, M.; Navas, J.M. Use of fish farms to assess river contamination: Combining biomarker responses, active biomonitoring, and chemical analysisd. Aquat. Toxicol. 2013, 140, 439-448. [CrossRef] [PubMed]

71. He, X.; Nie, X.; Wang, Z.; Cheng, Z.; Li, K.; Li, G.; Wong, M.H.; Liang, X.; Tsui, M.T.K. Assessment of typical pollutants in waterborne by combining active biomonitoring and integrated biomarkers response. Chemosphere 2011, 84, 1422-1431. [CrossRef]

72. Bahamonde, P.A.; Tetreault, G.R.; McMaster, M.E.; Servos, M.R.; Martyniuk, C.J.; Munkittrick, K.R. Molecular signatures in rainbow darter (Etheostoma caeruleum) inhabiting an urbanized river reach receiving wastewater effluents. Aquat. Toxicol. 2014, 148, 211-220. [CrossRef]

73. Casatta, N.; Stefani, F.; Vigano, L. Hepatic gene expression profiles of a non-model cyprinid (Barbus plebejus) chronically exposed to river sediments. Comp. Biochem. Physiol. C-Toxicol. Pharmacol. 2017, 196, 27-35. [CrossRef] [PubMed]

74. Herrero, O.; Planello, R.; Morcillo, G. The plasticizer benzyl butyl phthalate (BBP) alters the ecdysone hormone pathway, the cellular response to stress, the energy metabolism, and several detoxication mechanisms in Chironomus riparius larvae. Chemosphere 2015, 128, 266-277. [CrossRef]

75. Planello, R.; Servia, M.J.; Gomez-Sande, P.; Herrero, O.; Cobo, F.; Morcillo, G. Transcriptional Responses, Metabolic Activity and Mouthpart Deformities in Natural Populations of Chironomus riparius Larvae Exposed to Environmental Pollutants. Environ. Toxicol. 2015, 30, 383-395. [CrossRef]

76. Gagała, I.; Izydorczyk, K.; Jurczak, T.; Pawełczyk, J.; Dziadek, J.; Wojtal-Frankiewicz, A.; Jóźwik, A.; Jaskulska, A.; Mankiewicz-Boczek, J. Role of Environmental Factors and Toxic Genotypes in the Regulation of Microcystins-Producing Cyanobacterial Blooms. Microb. Ecol. 2014, 67, 465-479. [CrossRef]

77. Bourioug, M.; Mazzitelli, J.-Y.; Marty, P.; Budzinski, H.; Aleya, L.; Bonnafé, E.; Geret, F. Assessment of Lemna minor (duckweed) and Corbicula fluminea (freshwater clam) as potential indicators of contaminated aquatic ecosystems: Responses to presence of psychoactive drug mixtures. Environ. Sci. Pollut. Res. 2018, 25, 11192-11204. [CrossRef] [PubMed]

78. Paruch, L.; Paruch, A.M.; Blankenberg, A.-G.B.; Haarstad, K.; Mæhlum, T. Norwegian study on microbial source tracking for water quality control and pollution removal in constructed wetland treating catchment run-off. Water Sci. Technol. 2017, 76, 1158-1166. [CrossRef] [PubMed]

79. Berglund, B.; Khan, G.A.; Weisner, S.E.B.; Ehde, P.M.; Fick, J.; Lindgren, P.-E. Efficient removal of antibiotics in surface-flow constructed wetlands, with no observed impact on antibiotic resistance genes. Sci. Total Environ. 2014, 476-477, 29-37. [CrossRef] [PubMed]

80. Koerner, O.; Kohno, S.; Schoenenberger, R.; Suter, M.J.-F.; Knauer, K.; Guillette, L.J., Jr.; Burkhardt-Holm, P. Water temperature and concomitant waterborne ethinylestradiol exposure affects the vitellogenin expression in juvenile brown trout (Salmo trutta). Aquat. Toxicol. 2008, 90, 188-196. [CrossRef] 
81. Giroux, M.; Gan, J.; Schlenk, D. The effects of bifenthrin and temperature on the endocrinology of juvenile Chinook salmon. Environ. Toxicol. Chem. 2019, 38, 852-861. [CrossRef]

82. Muniz-Gonzalez, A.-B.; Martinez-Guitarte, J.-L. Combined effects of benzophenone-3 and temperature on gene expression and enzymatic activity in the aquatic larvae Chironomus riparius. Sci. Total Environ. 2020, 698. [CrossRef]

83. Hahn, C.M.; Iwanowicz, L.R.; Cornman, R.S.; Mazik, P.M.; Blazer, V.S. Transcriptome discovery in non-model wild fish species for the development of quantitative transcript abundance assays. Comp. Biochem. Physiol. Part D Genom. Proteom. 2016, 20, 27-40. [CrossRef]

84. Blazer, V.S.; Walsh, H.L.; Shaw, C.H.; Iwanowicz, L.R.; Braham, R.P.; Mazik, P.M. Indicators of exposure to estrogenic compounds at Great Lakes Areas of Concern: Species and site comparisons. Environ. Monit. Assess. 2018, 190. [CrossRef]

85. Zhang, Z.; Liu, W.; Qu, Y.; Quan, X.; Zeng, P.; He, M.; Zhou, Y.; Liu, R. Transcriptomic Profiles in Zebrafish Liver Permit the Discrimination of Surface Water with Pollution Gradient and Different Discharges. Int. J. Environ. Res. Public Health 2018, 15, 1648. [CrossRef]

86. Bebianno, M.J.; Sroda, S.; Gomes, T.; Chan, P.; Bonnafe, E.; Budzinski, H.; Geret, F. Proteomic changes in Corbicula fluminea exposed to wastewater from a psychiatric hospital. Environ. Sci. Pollut. Res. 2016, 23, 5046-5055. [CrossRef]

87. Riva, C.; Cristoni, S.; Binelli, A. Effects of triclosan in the freshwater mussel Dreissena polymorpha: A proteomic investigation. Aquat. Toxicol. 2012, 118-119, 62-71. [CrossRef] [PubMed]

88. Simmons, D.B.D.; Miller, J.; Clarence, S.; McCallum, E.S.; Balshine, S.; Chandramouli, B.; Cosgrove, J.; Sherry, J.P. Altered expression of metabolites and proteins in wild and caged fish exposed to wastewater effluents in situ. Sci. Rep. 2017, 7, 17000. [CrossRef] [PubMed]

89. Yan, Q.; Gao, X.; Guo, J.; Zhu, Z.; Feng, G. Insights into the molecular mechanism of the responses for Cyperus alternifolius to PhACs stress in constructed wetlands. Chemosphere 2016, 164, 278-289. [CrossRef]

90. Chen, E.Y.; Liu, W.F.; Megido, L.; Díez, P.; Fuentes, M.; Fager, C.; Olsson, E.; Gessner, I.; Mathur, S. Understanding and utilizing the biomolecule/nanosystems interface. In Nanotechnologies in Preventive and Regenerative Medicine; Elsevier: Amsterdam, The Netherlands, 2018; pp. 207-297.

91. Zhou, N.A.; Kjeldal, H.; Gough, H.L.; Nielsen, J.L. Identification of Putative Genes Involved in Bisphenol A Degradation Using Differential Protein Abundance Analysis of Sphingobium sp. BiD. Environ. Sci. Technol. 2015, 49, 12232-12241. [CrossRef] [PubMed]

92. Kohler, R. Landscapes and Labscapes: Exploring the Lab.-Field Border in Biology; University of Chicago Press: Chicago, IL, USA, 2002; ISBN 9780226450100.

Publisher's Note: MDPI stays neutral with regard to jurisdictional claims in published maps and institutional affiliations.

(C) 2020 by the authors. Licensee MDPI, Basel, Switzerland. This article is an open access article distributed under the terms and conditions of the Creative Commons Attribution (CC BY) license (http://creativecommons.org/licenses/by/4.0/). 